\title{
INTERNATIONAL JOURNAL OF FIELD EDUCATION
}

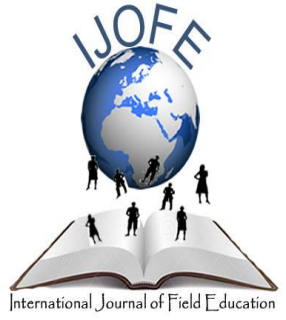

\section{Investigation of PISA Problem Posing Skills of Mathematics Teacher Candidates*}

\author{
Ömer Şahin ${ }^{1}$ \\ Amasya University, Faculty of Education \\ http://orcid.org/0000-0001-7449-3627 \\ Murat Başgül ${ }^{2}$ \\ Amasya University, Faculty of Education \\ http://orcid.org/0000-0002-7366-0427
}

\begin{abstract}
In this study, mathematics teacher candidates' problem posing skills appropriate to the nature of PISA were investigated in this study. The case study method, one of the qualitative research methods, was used in the study. Participants of the study are constituted of 55 mathematics teacher candidates studying in education faculty of a university. In the study, initially, teacher candidates were educated about PISA exam. During the education, knowledge about the purpose of PISA and held by whom, which skills are assessed, how the questions are prepared and evaluated, which features the questions have and information about the performances of the other countries were given. Later the questions which were placed in PISA were analyzed under categories of context, content, process skills and question types. Teacher candidates were also given detailed information on how these questions were evaluated. After this training, teacher candidates were given a research project to prepare three questions appropriate to the nature of PISA. The problems that teacher candidates have prepared are analyzed by two researchers with the data analysis framework developed by the researchers. As a result of the study, it has been found that many of the problems that teacher candidates have posed are appropriate to the nature of PISA. In addition, it has been seen that the teacher candidates usually posed openended problems, but they less prefer to pose multiple-choice and shortanswer problems. When teacher candidates' problems are examined in terms of content, context and process skills, it has been determined that they most posed problems in the content of quantity (Numbers and Operations), in the personal and occupational context and generative skill oriented. In addition, most of the teacher candidates made an explanation for the exactly correct category and the zero categories for evaluating the problems they posed, but not for the partially correct category.
\end{abstract}

Received: 15.11 .2018

Revision received:

10.12.2018

Accepted: 30.12 .2018

Published online:

31.12.2018

\footnotetext{
${ }^{1}$ Corresponding author:

mersahin60@gmail.com

${ }^{2}$ muratbasgul60@gmail.com

* This study was presented in the 'International Conference on Mathematics and Mathematics Educations (ICMME-2018)' (27-29 June 2018, Ordu).
} 


\title{
Matematik Öğretmeni Adaylarının PISA Problemi Kurma Becerilerinin İncelenmesi*
}

\author{
Ömer Şahin ${ }^{1}$ \\ Amasya Üniversitesi, Ĕgitim Fakültesi \\ http://orcid.org/0000-0001-7449-3627 \\ Murat Başgül ${ }^{2}$ \\ Amasya Üniversitesi, Ĕgitim Fakültesi \\ http://orcid.org/0000-0002-7366-0427
}

\section{ÖZET}

MAKALE BILGISI

Bu çalışmada matematik öğretmeni adaylarının PISA' nın doğasına uygun problem kurma becerileri incelenmiştir. Bu çalışmada nitel araştırma yöntemlerinden durum çalışması kullanılmıştır. Çalışmanın katılımcılarını bir üniversitenin eğitim fakültesinde öğrenim gören 55 matematik öğretmeni adayı oluşturmaktadır. Bu çalışmada ilk olarak öğretmen adaylarına PISA sınavı hakkında eğitim verilmiştir. Bu eğitimde PISA sınavının amacı, kimler tarafından yapıldığı, hangi becerileri ölçtüğg̈, soruların nasıl değerlendirildiği, soruların nasıl hazırlandığı, soruların hangi özelliklere sahip olduğu ve ülkelerin başarı durumları hakkında bilgi verilmiştir. Daha sonra PISA sınavlarında yer verilmiş sorular; bağlam, içerik, süreç becerileri, soru türleri gibi çeşitli kategoriler altında analiz edilmiştir. Ayrıca bu soruların nasıl değerlendirdiği hakkında da öğretmen adaylarına detaylı bilgi verilmiştir. Bu eğitimden sonra öğretmen adaylarından PISA' nın doğasına uygun üç soru hazırlamaları için bir araştırma ödevi verilmiştir. Öğretmen adaylarının hazırlamış oldukları problemler araştırmacı tarafından geliştirilen veri analiz çerçevesi yardımıyla iki araştırmacı tarafından analiz edilmiştir. Çalışma sonucunda öğretmen adaylarının kurdukları problemlerin birçoğunun PISA'nın doğasına uygun olduğu görülmüştür. Ayrıca öğretmen adaylarının genellikle açık uçlu problemler kurdukları buna rağmen çoktan seçmeli ve kısa cevap gerektiren problemleri ise daha az tercih ettikleri görülmüştür. Öğretmen adayların kurdukları problemler içerik, bağlam ve süreç becerileri açısından incelendiğinde ise en fazla nicelik (Sayılar ve İşlemler) içeriğinde, kişisel ve mesleki bağlamda ve üretici beceriye dönük problemler kurdukları belirlenmiştir. Bunlara ek olarak öğretmen adaylarının birçoğu kurdukları problemlerin değerlendirilmesine dönük tam doğru ve sıfır kategorisi için açıklama yaparken kısmen doğru kategorisi için açıklama yapmamışlardır.

Alınma

Tarihi:15.11.2018

Düzeltilmş hali alınma

tarihi: 10.12 .2018

Kabul Edilme Tarhi:

30.12.2018

Çevrimiçi yayınlanma tarihi: 31.12.2018

\footnotetext{
${ }^{1}$ Sorumlu yazar iletişim bilgileri:

mersahin60@gmail.com

${ }^{2}$ muratbasgul60@gmail.com

*Bu çalışma "International Conference on Mathematics and Mathematics Educations (ICMME-2018)" de sözlü bildiri

olarak sunulmuştur.
} 


\section{Giriș}

Değişen ve gelişen dünyanın gereksinimlerine cevap verebilecek niteliklere sahip bireyler yetiştirmek ancak eğitimle mümkün olabilmektedir. $\mathrm{Bu}$ nedenle ülkeler eğitim programlarını çağın gereksinimlerine uygun şekilde yenileme ihtiyacı duymaktadır. Uluslararası platformda en yaygın katılımın olduğu etkinlikler arasında olan ve düzenli aralıklarla gerçekleştirilen PISA (Programme for International Student Assessment) projesi ülkelere kendi eğitim programlarını değerlendirme ve yorumlama imkanı vermektedir (Güzeller, Eser ve Aksu, 2016). 2015'te yapılan PISA sınavına 72 ülkeden yaklaşık 540000 (Milli Eğitim Bakanlığı [MEB], 2016) öğrencinin katıldığı düşünüldügünde Türkiye'nin eğitim programı sonuçlarının diğer ülkelerle karşılaştırması açısından önemli bir firsat olduğu görülmektedir.

PISA projesi ülkemizin de üye olduğu OECD (Organisation for Economic Co-operation and Development) organizasyonu tarafından 15 yaş grubu öğrencilerin matematik, okuma ve fen bilgisi alanında başarılarını değerlendirmek amacıyla üç yılda bir düzenli olarak gerçekleştirilmektedir (OECD, 2018). Her dönem farklı bir alana ağırlık verildiği bu sınavda 2003 ve 2012 yıllarında matematik alanına ağırlık verilmiştir. PISA etkinliğinde öğrencilerin matematik bilgilerinin belirlenmesinden çok sahip oldukları matematik okuryazarlığını gerçek yaşam durumlarında karşılaşacakları problemleri çözmede ne derece kullanabildiklerinin belirlenmesi hedeflenmektedir (OECD, 2013a, 2013b). PISA Matematik okuryazarlığ 1 genel değerlendirme ölçütleri incelendiğinde üretici, ilişkilendirici ve yansitıcı becerilerin kullanımının öne çıktığı Matematik alanında soru içerikleri; nicelik, uzay ve şekil, değişim ve ilişkiler ve belirsizlik olmak üzere dört farklı kategoride ele alınmaktadır. Ayrıca gerçek yaşam durumlarında ortaya çıkan problemlerle ilgili olması ve daha sağlıklı ölçüm yapılabilmesi amaciyla PISA Matematik okuryazarlığı alanında sorular; bilimsel, mesleki, toplumsal ve bireysel bağlama uygun olarak hazırlanmıştır (MEB, 2016). PISA matematik sorularının madde tipleri incelendiğinde çoktan seçmeli, karmaşık çoktan seçmeli, kısa yanıt gerektiren kapalı uçlu, kısa yanıt gerektiren açık uçlu ve uzun yanıt gerektiren açık uçlu olmak üzere 5 madde tipi bulunmaktadır (MEB, 2011).

Literatür incelendiğinde Türkiye'nin PISA sonuçlarını değerlendirmeye yönelik yapılan çalışmalar istenilen başarının yakalanamadığını ortaya koymaktadır (Berberoğlu, 2007; Özer ve Özberk, 2011; Özer ve Anıl, 2011; Altun, Aydın, Akkaya ve Uzel, 2012; MEB PISA Raporu, 2016). Katılımcı ülkelerin 1 en düşük; 6 en yüksek seviye olacak şekilde değerlendirildiği PISA etkinliğinde Türkiye 2003 ve 2009 sonuçlarında tüm alanlarda 2. seviyede yer aldığı görülmüştür (Özenç ve Arslanhan, 2010). PISA 2012 sonuçları incelendiğinde Türkiye Matematik okuryazarlığı alanında 65 ülke arasından 44. sirada yer almaktadır. OECD ortalamasının 494 olduğu 2012 PISA'da Türkiye ortalaması 448 puanla OECD ülkelerinin gerisinde kalmıştır. Ayrıca PISA 2015 Matematik okuryazarlığı alanı sonuçlarına bakıldığında Türkiye ortalamasının 420, OECD ortalamasının 490, katılan toplam 72 ülke ortalamasının 461 olduğu ve Türkiye'nin hem OECD hem de tüm ülkeler ortalamasının gerisinde kaldığı anlaşılmaktadır (MEB, 2016).

Türkiye'nin PISA sonuçları PISA matematik okuryazarlığı alanındaki sorulara Türkiye'deki öğrencilerin ne kadar hazır oldukları sorusunu akla getirmektedir. PISA matematik okuryazarlığı tanımına bakıldığında "çeşitli bağlamlarda bireyin formüle etme, matematiği kullanma ve yorumlama kapasitesi" olarak tanımlanmaktadır (MEB, 2016). Bu noktada öğretmenler eğitimin en önemli bileşenlerinden biri olarak (Ball, Thames, Phelps, 2008) öğrencilerin matematik okuryazarlığı becerilerinin arttırılması ve onları PISA 
sorularına daha hazırlıklı hale getirilmesinde kritik önem kazanmaktadır. Matematik eğitiminin en önemli amaçlarından biri öğrencilerin problem çözme becerilerini geliştirerek karşılaşabilecekleri problemlerle rahatlıkla baş edebilmelerini sağlamaktır (Kılıç, 2013; Ersoy, 1997). Bu bağlamda öğretmenlerin ve geleceğin öğretmenleri olan öğretmen adaylarının problem kurma becerileri ön plana çıkmaktadır.

Problem çözümü bilinmeyen, bireyi rahatsız eden, zor ve farklı stratejilerin kullanımını gerektiren durumlar olarak; problem çözme ise bu durumları ortadan kaldırmak için zihinsel süreçlerle gerekli bilgililerin kullanılması şeklinde tanımlanmaktadır (Altun, 2008). Polya'nın problem çözme basamaklarından beşincisi olan (Gonzales, 1998) problem kurma ise mevcut durumdan hareketle yeni bir problem oluşturma şeklinde tanımlanmaktadır (Stoyanova ve Ellerton, 1996). Yapılan çalışmalar (Kilpatrick, 1987; Lowrie, 2002; Cankoy \& Darbaz, 2010; Stoyanova ve Ellerton, 1996; Stoyanova, 2003; Silver ve Cai, 1996; English, 1997) problem çözme ve problem kurma arasında ilişki olduğunu ortaya koymaktadır. Silver ve Cai (1996) çalışmalarında problem kurmanın; problem çözme, matematiksel düşünme ve yaratıcılık becerilerini geliştirdiğini ifade etmiştir. English (1997) problem kurmanın temel matematiksel kavramların pekiştirilmesi ve problem kurma becerilerinin arttırılmasında etkili bir yol olduğunu belirtmiştir. Problem kurma mevcut problemin çözümünden hareketle yeni bir problem oluşturmanın yanında verilen problemi düzenleyerek yeniden kurma anlamına da gelebilmektedir. Böylece çözümü zor olan problemler daha basit benzer problemler şeklinde yeniden düzenlenerek çözümü kolaylaştırılabilir (Silver, 1994). Bu nedenle öğretmenlerin problem çözme ve kurma becerilerini etkin bir şekilde kullanabilmeleri; öğrencilerini farklı türde ve daha zengin içerikte problemlerle karşı karşıya gelmelerini sağlayarak; muhakeme becerilerinin gelişmesini ve günlük hayatla problem arasında ilişki kurabilmelerine katkıda bulunacaktır (Akay, Soybaş ve Argün, 2006).

İlgili çalışmalarda öğretmen adaylarının kurduğu problemlerin genel olarak ders kitaplarındaki problemlerle benzerlik gösterdiği, zengin içerikli ve üst düzey düşünme becerileri gerektiren karmaşık problemler kurmada zorlandıkları ortaya konulmuş ve bunun nedeni olarak problem kurma ile ilgili yeterli deneyime sahip olamamaları gösterilmiştir (Korkmaz ve Gür, 2006; Çelik ve Özdemir, 2011; Işık, Işı1k ve Kar 2011; Rosli vd., 2015; Xie \& Masingila, 2017). Bu noktada öğretmen adaylarının PISA problemleri kurma ile ilgili becerilerini inceleyen bu çalışma konuyla ilgili literatüre katkıda bulunması açısından önem arz etmektedir. Bu bağlamda bu çalışmada ortaokul matematik öğretmeni adaylarının PISA problemi kurma becerilerinin incelenmesi amaçlanmıştır.

\section{Yöntem}

$\mathrm{Bu}$ araştırmada matematik öğretmen adaylarının PISA problemleri kurma becerilerini incelemek amacıyla nitel araştırma yöntemlerinden birisi olan durum çalışması kullanılmıştır. Durum çalışması yönteminde; bir olay, durum, ilişki veya süreç sınırlı sayıda örneklem yardımıyla derinlemesine incelenir (Denscombe, 2010). Durum çalışması yönteminde yer alan durumlar; kişiler, öğretim programları, gruplar (topluluklar), davranışlar, olaylar incelenir (Creswell, 2011; Neuman, 2014; Yin, 2012). Bu çalışmanın durumunu ise; matematik öğretmeni adaylarının PISA problemi kurabilme becerileri oluşturmaktadır.

\section{Katılımcilar}

Bu çalışmanın katılımcılarını; amaçsal örneklem yöntemiyle seçilen, Türkiye' de yer alan bir üniversitenin eğitim fakültesinin ilköğretim matematik öğretmenliğgi bölümünde öğrenim gören 55 üçüncü sınıf öğretmen adayı oluşturmaktadır. Amaçsal örnekleme 
yönteminde; çalışmanın katılımcılarının belirlenmesinde çeşitli kriterler dikkate alınır (Patton, 1987). Bu çalışmada kullanılan ölçüt ise, katılımcılarda matematiksel problem kurma becerisinin olması gerekliliğidir. Çünkü ilköğretim matematik öğretmeni adaylarının lisans eğitimleri bittikten sonra, öğretmen olduklarında ortaokul öğrencilerinin problem çözme ve kurmalarına yönelik öğretim faaliyetleri gerçekleştirmeleri gerekmektedir. Ayrıca veri toplama sürecinde araştırmanın etiği çerçevesinde öğretmen adaylarının gerçek isimleri metin içinde kullanılmamıştır. Bu bağlamda, çalışmaya katılan öğretmen adaylarına ÖA1'den ÖA55'e kadar kodlar verilmiştir.

\section{Veri toplama Süreci}

$\mathrm{Bu}$ çalışmada nitel veri toplama tekniklerinden doküman incelemesi (documents and artifact collection method) veri toplama aracı olarak tercih edilmiştir. Çünkü dökümanlar nitel araștırmalarda sık kullanılan ve zengin veri sağlayan bilgi kaynaklarından birisidir (Yıldırım ve Şimşek, 2011). Doküman incelemesi yönteminde, araştırmanın amacı doğrultusunda veri elde edilmesini sağlayan yazılı, sözlü ve görsel materyaller kullanılabilir (McMillian ve Schumacher, 2010; Yıldırım ve Şimşek, 2011). Bu çalışmada ise öğretmen adaylarının Özel Öğretim Yöntemleri II dersi kapsamında PISA ile ilgili yaptıkları ödevler veri toplama aracı olarak kullanılmıştır.

İlk olarak öğretmen adaylarına matematik problem durumları, problemlerin sınıflandırılması, problem çözme adımları, problem çözme stratejileri ve problem kurma ile ilgili 10 saatlik bir eğitim verilmiştir. Öğretmen adaylarına daha sonra PISA sınavının araştırılmasına ilişskin bir ödev verilmiştir. Bu ödevde, öğretmen adaylarının PISA sınavıyla ilgili sorulara cevap aramaları istenmiştir. Örneğin, "PISA sinavindan hangi beceriler ölçülür?", "PISA sinavında yer alan soruların bağlamaları nelerdir?" "PISA sinavında hangi ögrenme alanlarına yer verilmektedir?" gibi sorulara bu ödevde yer verilmiştir. Daha sonra öğretmen adaylarına PISA sınavının tüm yönleriyle tanıtılmasına yönelik 2 saatlik bir eğitim verilmiştir. Veri toplamanın son aşamasında ise öğretmen adaylarından PISA sınavının doğasına uygun üç problem kurmaları ve kurdukları problemlerin veri analiz çerçevelerini oluşturmaları için iki hafta süre verilmiştir.

\section{Verilerin Analizi}

$\mathrm{Bu}$ çalışmada öğretmen adaylarının kurdukları problemler nitel veri analiz yöntemlerinden betimsel analiz tekniği ile analiz edilmiştir. Betimsel analiz tekniğinde araştırmacı, daha önceden geliştirilmiş temalar ve kodlar yardımıyla elde ettiği verileri analiz edebilir (Yıldırım ve Şimşek, 2011). Ayrıca betimsel analiz tekniğinde verilerin elde edildiği gözlem, görüşme veya dokümanlardan doğrudan alıntılara yer verilebilir. Bu araştırmanın kodları ise PISA sınavında kullanılan terminoloji bağlamında oluşturulmuştur. Bu bağlamda örnek bir veri analiz çerçevesi aşağıda yer alan Tablo 1' de yer almaktadır.

Tablo 1. Veri analiz çerçevesi

\begin{tabular}{ll}
\hline Bağlam & \multicolumn{1}{c}{ Göstergeler } \\
\hline Kişisel & $\begin{array}{l}\text { Bu bağlamdaki problemler; bireyin yemek yapma, alışveriş, oyun, eğlence gibi günlük } \\
\text { yaşam rutinlerinden oluşan durumlart içermektedir. } \\
\text { Mesleki bağlamdaki problemler; bir meslek grubunda yer alan faaliyetlere yönelik } \\
\text { Burumlart içermektedir. }\end{array}$ \\
$\begin{array}{l}\text { Toplums } \\
\text { al }\end{array}$ & $\begin{array}{l}\text { Bu bağlamda yer alan problemler; genellikle toplu taşıma, seçim, nüfus sayımı gibi } \\
\text { Bilimsel }\end{array}$ \\
& $\begin{array}{l}\text { Bu bağlamdaki problemlerde; tıp, fizik, kimya, astronomi gibi bir bilim dalında } \\
\text { (disiplin) yer alan durumlart içermektedir. }\end{array}$
\end{tabular}


Yok

Tablo 1' de öğretmen adaylarının kurdukları problemlerin bağlam açısından incelenmesine yönelik göstergelere yer verilmiştir. Örneğin öğretmen adayları kurdukları problemleri; tıp, fizik, kimya, astronomi gibi bir bilim dalında (disiplin) yer alan durumların üzerine inşa etmişlerse problem bilimsel bağlam olarak kodlanmıştır.

Çalışmanın güvenirliğini sağlamak için öğretmen adaylarının PISA' ya yönelik kurdukları problemler iki araştırmacı tarafından kodlanmıştır. Bağımsız iki araştırmacı tarafından yapılan kodlamalarda puanlamanın güvenirliğini kontrol etmek için kodlama güvenirliğinin incelenmesi gerekmektedir. Puanlama güvenirliğinin kabul edilebilir olması için kodlama güvenirlik yüzdesinin en az \%70 seviyesinde olması gerekmektedir (Yıldırım ve Şimşek, 2011). Bu çalışmada ilk olarak veriler iki araştırmacı tarafından bağımsız olarak kodlanmıştır. Daha sonra araştırmacılar bir araya gelerek yapılan kodlamaları karşılaştırmışlardır. Kodlamaların benzerliklerini ve farklılıklarını sayısal olarak karşılaştırıldıktan sonra kodlama güvenirlik yüzdesi \% 83 olarak hesaplanmıştır. Daha sonra araştırmacılar bir araya gelerek farklılaşma olan kodlamalar üzerinde uzlaşmaya vararak veri analiz süreci tamamlanmıştır. Diğer bir ifadeyle iki puanlayıcı tüm kodlamalar üzerinde uzlaşmaya vardıktan sonra veri analiz süreci tamamlanmıştır.

\section{Bulgular}

Çalışmanın bu bölümünde öğretmen adaylarının kurmuş oldukları problemlerin PISA'ya uygunluk, soru türü, bağlam, içerik, süreç becerileri gibi farklı değişkenler açısından analiz edilmesiyle elde edilen bulgular tablolar ve doğrudan alıntılar halinde sunulmuştur.

\section{Problemlerin PISA Doğasına Uygunluğu}

Aşağıda yer alan Tablo 2' de öğretmen adaylarının kurmuş oldukları problemlerin PISA'nın doğasına uygun olup olmadıklarına ait bulgular yer almaktadır.

Tablo 2. Öğretmen adaylarının kurdukları problemlerinin PISA doğasına uygunluğu

\begin{tabular}{lcccccccc}
\hline Problemler & \multicolumn{2}{c}{ Problem 1 } & \multicolumn{2}{c}{ Problem 2 } & \multicolumn{2}{c}{ Problem 3 } & \multicolumn{2}{c}{ Toplam } \\
\hline PISA Doğası & $\mathrm{f}$ & $\%$ & $\mathrm{f}$ & $\%$ & $\mathrm{f}$ & $\%$ & $\mathrm{f}$ & $\%$ \\
PISA Doğasına Uygun & 47 & 85.45 & 43 & 78.18 & 49 & 89.09 & 139 & 84.25 \\
$\begin{array}{l}\text { PISA Doğasına Uygun } \\
\text { Değil }\end{array}$ & 8 & 14.54 & 12 & 21.81 & 6 & 10.9 & 26 & 15.75 \\
\hline Toplam & 55 & 100 & 55 & 100 & 55 & 100 & 165 & 100 \\
\hline
\end{tabular}

Tablo 2' de, ortaokul matematik öğretmeni adaylarının PISA' nın doğasına uygun problem kurabilmekte başarılı oldukları görülmektedir. Çünkü öğretmen adaylarının kurdukları problemler hep beraber değerlendirildiğinde, matematik öğretmeni adaylarının kurdukları problemlerin \% 84.25' nin PISA' nın doğasına uygun olduğu görülmektedir.

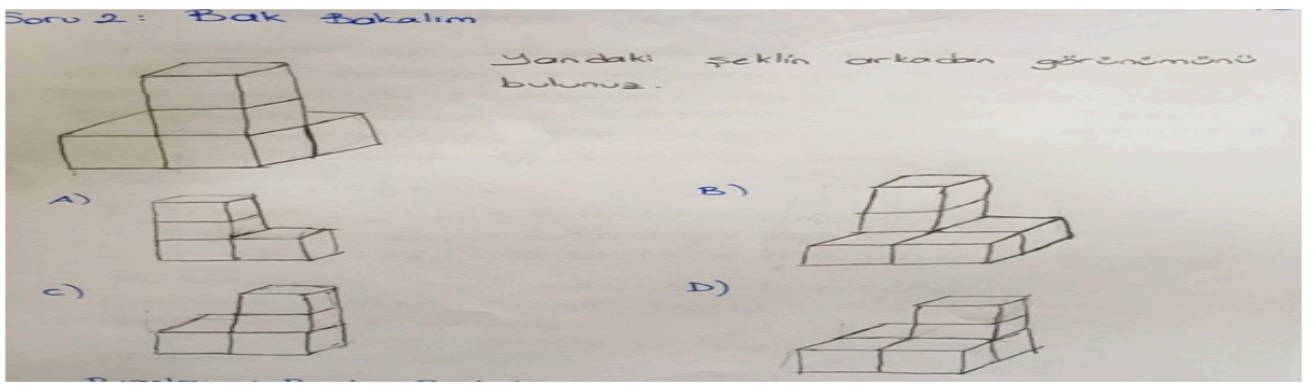

Şekil 1. ÖA11' in kurmuş olduğu ikinci problem 
Şekil 1' de ÖA11 öğretmen adayının kurmuş olduğu problem incelendiğinde, bu problemin PISA' nın doğasına uygun olmadığı görülmektedir. Çünkü öğretmen adayının kurmuş olduğu problemde mesleki, bilimsel, toplumsal veya kişisel herhangi bir bağlama yer verilmemiştir. Dolayısıyla, öğretmen adayı kurmuş olduğu problemde günlük yaşamla ilişki kurmamıştır.

\section{Problemlerin Soru Türleri}

Aşağıda yer alan Tablo 3' de öğretmen adaylarının kurmuş oldukları problemlerin PISA soru türleri açısından incelenmesine ait bulgular yer almaktadır.

Tablo 3. Öğretmen adaylarının kurdukları problemlerinin soru türleri

\begin{tabular}{lcccccccc}
\hline Problemler & \multicolumn{2}{c}{ Problem 1 } & \multicolumn{2}{c}{ Problem 2 } & \multicolumn{2}{c}{ Problem 3 } & \multicolumn{2}{c}{ Toplam } \\
\hline Soru Türleri & $\mathrm{f}$ & $\%$ & $\mathrm{f}$ & $\%$ & $\mathrm{f}$ & $\%$ & $\mathrm{f}$ & $\%$ \\
\hline Açık Uçlu & 37 & 67.27 & 30 & 54.54 & 32 & 58.18 & 99 & 60 \\
Çoktan Seçmeli & 13 & 23.63 & 19 & 34.54 & 19 & 34.54 & 51 & 30.9 \\
Kısa Cevap & 5 & 9.09 & 6 & 10.9 & 4 & 7.27 & 15 & 9.09 \\
\hline Toplam & 55 & 100 & 55 & 100 & 55 & 100 & 165 & 100
\end{tabular}

Tablo 3' de öğretmen adaylarının daha çok (\% 60) açık uçlu problemler kurmayı tercih ettikleri görülmektedir. Buna rağmen öğretmen adayları kısa cevap gerektiren problemleri ise çok az (\% 9.09) tercih ettikleri görülmektedir. Bu bağlamda; ÖA42, ÖA32 ve ÖA39 öğretmen adaylarının kurmuş oldukları problemlerden PISA soru türlerine ait farklı örneklere yer verilmiştir.

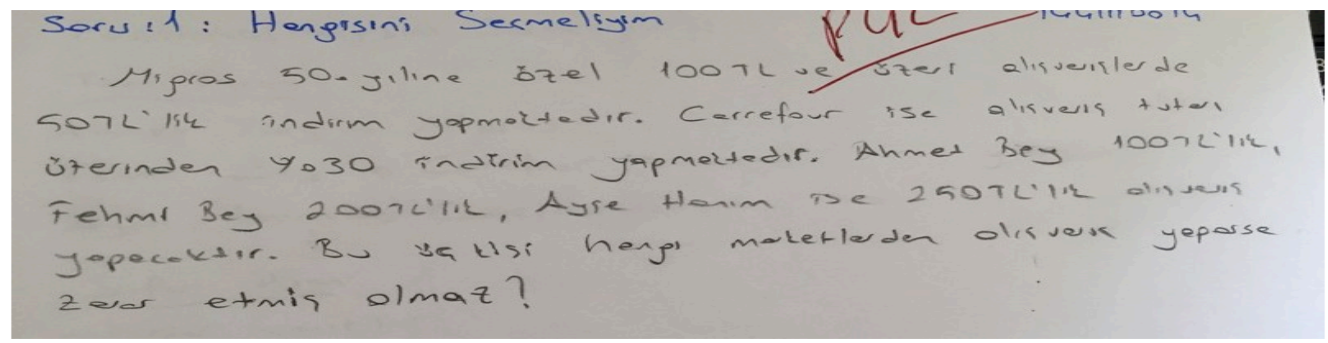

Şekil 2. ÖA42' nin kurmuş olduğu açık uçlu problem

ÖA42 öğretmen adayı iki farklı marketin sunmuş olduğu indirimleri vermiştir. Öğretmen adayı problem durumunda Ahmet Bey ve Fehmi Bey’ in hangi marketten alış-veriş yaptıklarında daha karlı olacaklarını sormuştur. $\mathrm{Bu}$ soruda öğrencilerden beklenen iki marketin sağlamış oldukları indirimleri kontrol ederek kişilerin kar-zarar durumunu hesaplayıp karşılaştırma yapmalarını sağlamaktır.

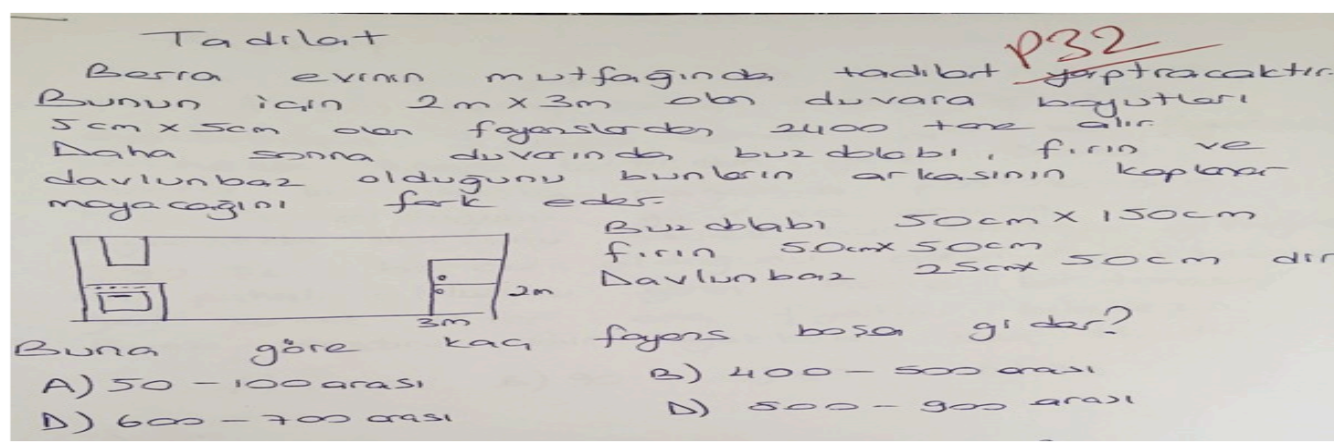

Şekil 3. ÖA32' nin kurmuş olduğu çoktan seçmeli problem 
ÖA32 öğretmen adayı mutfakta yapılan bir tadilat işleminde ne kadar fayans gerektiğine dair bir problem kurmuştur. Öğretmen adayı kurmuş olduğu problemde çıkabilecek muhtemel sonuçları seçenekler halinde öğrencilere sunarak problemi çoktan seçmeli bir forma dönüştürmüştür.

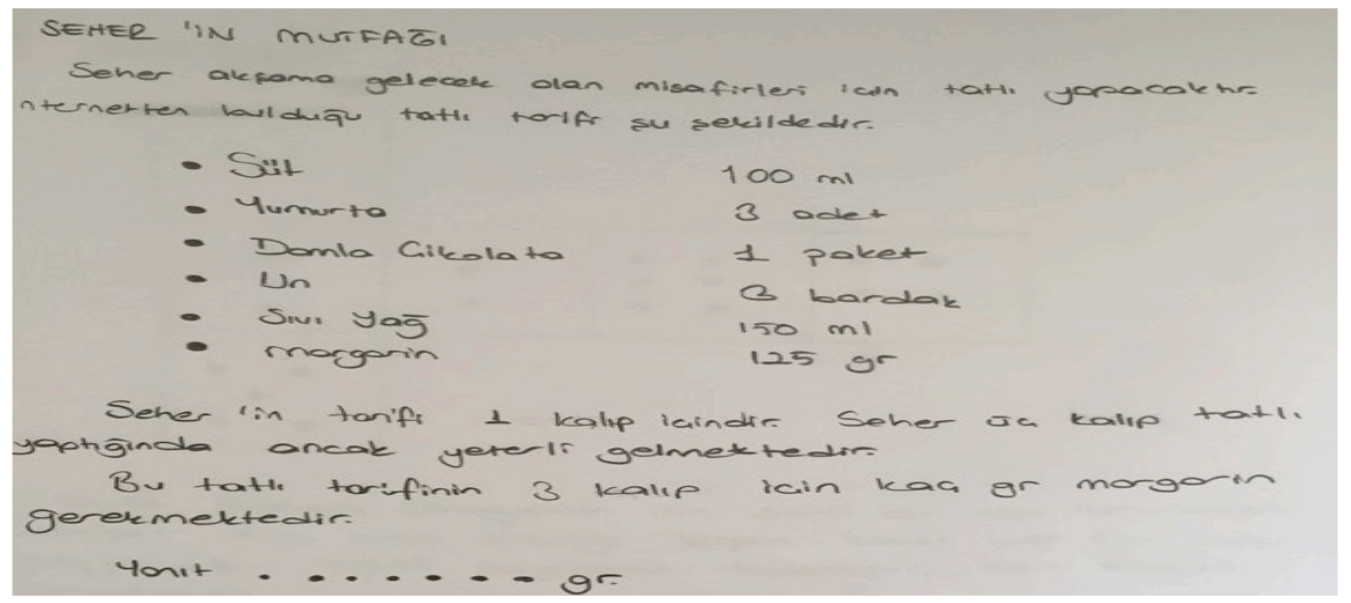

Şekil 4. ÖA39' un kurmuş olduğu kisa cevaplı problem

ÖA39 öğretmen adayı ise bir kalıp kek yapımında kullanılan malzeme miktarlarını vermiş̧tir. Öğretmen adayı öğrencilerden 3 kalıp kek yapıldığında ne kadar margarin gerektiğini sormuştur. Öğretmen adayı öğrencilerden sadece doğru cevabı bırakılan boşluğa yazmalarını isteyerek kısa cevap gerektiren bir problem kurmuştur.

\section{Problemlerin Bağlamlart}

Aşağıda yer alan Tablo 4' de öğretmen adaylarının kurmuş oldukları problemlerin PISA bağlamları açısından incelenmesine ait bulgular yer almaktadır.

Tablo 4. Öğretmen adaylarının kurdukları PISA problemlerinin bağlamları

\begin{tabular}{lcccccccc}
\hline Problemler & \multicolumn{2}{c}{ Problem 1 } & \multicolumn{2}{c}{ Problem 2 } & \multicolumn{2}{c}{ Problem 3 } & \multicolumn{2}{c}{ Toplam } \\
\hline Bağlam & $\mathrm{f}$ & $\%$ & $\mathrm{f}$ & $\%$ & $\mathrm{f}$ & $\%$ & $\mathrm{f}$ & $\%$ \\
\hline Kişisel & 18 & 32.72 & 21 & 38.18 & 17 & 30.9 & 56 & 33.93 \\
Mesleki & 19 & 34.54 & 20 & 36.36 & 20 & 36.36 & 59 & 35.75 \\
Toplumsal & 10 & 18.18 & 7 & 12.72 & 6 & 10.9 & 23 & 13.93 \\
Bilimsel & 6 & 10.9 & 4 & 7.27 & 9 & 16.36 & 19 & 11.51 \\
Bağlam Yok & 2 & 3.63 & 3 & 5.45 & 3 & 5.45 & 8 & 4.84 \\
\hline Toplam & 55 & 100 & 55 & 100 & 55 & 100 & 165 & 100 \\
\hline
\end{tabular}

Tablo 4' de öğretmen adaylarının daha çok kişisel (\% 33.93) ve mesleki (\% 35.75) bağlamlara yönelik problemler kurabildikleri görülmektedir. Buna rağmen öğretmen adayları toplumsal $(\%$ 13.93) ve bilimsel $(\%$ 11.51) bağlamlara yönelik ise daha az problem kurdukları söylenebilir. Ayrıca çok az sayıda (\% 4.84) öğretmen adayı ise kurdukları problemlere herhangi bir bağlama yer vermemişlerdir. Bu bağlamda, ÖA7, ÖA10, ÖA45 ve ÖA23 öğretmen adaylarının farklı bağlamlarda kurmuş oldukları problem örneklerine yer verilmiştir. 


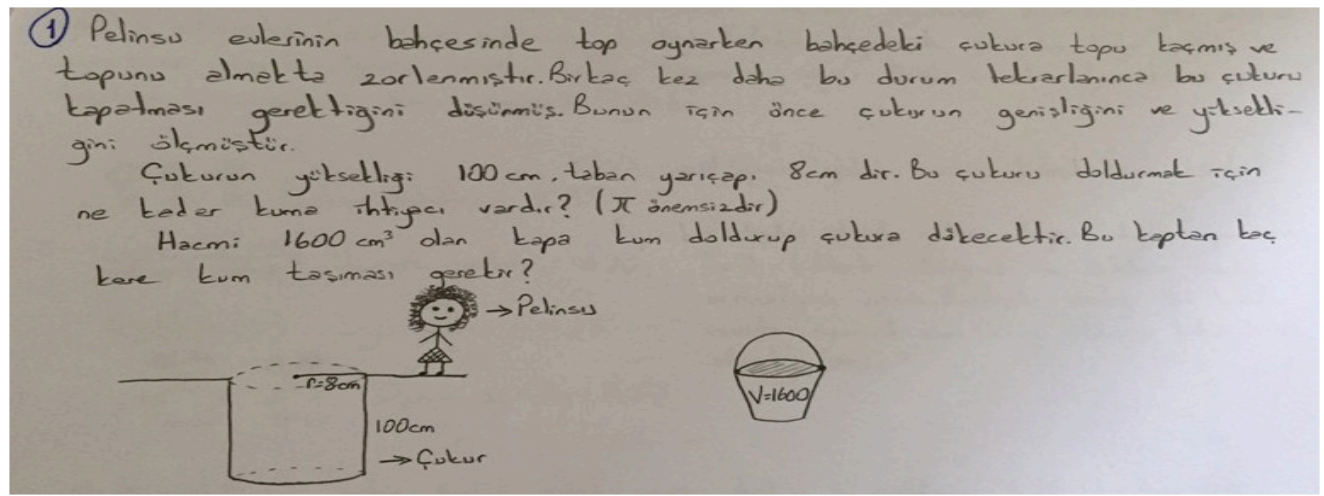

Şekil 5. ÖA7’ nin kurmuş olduğu kişisel bağlaml problem

ÖA7 öğretmen adayı bir çocuğun bahçesinde oyun oynarken çukura düşen topunu kurtarmak için ne kadar kum ile çukuru doldurabileceğine dair kişisel bağlamda bir problem kurmuştur. $\mathrm{Bu}$ problemin kişisel bağlamda değerlendirilmesinin gerekçesi; bireyin kendi hayatını ilgilendiren bir aktivite içermesidir.

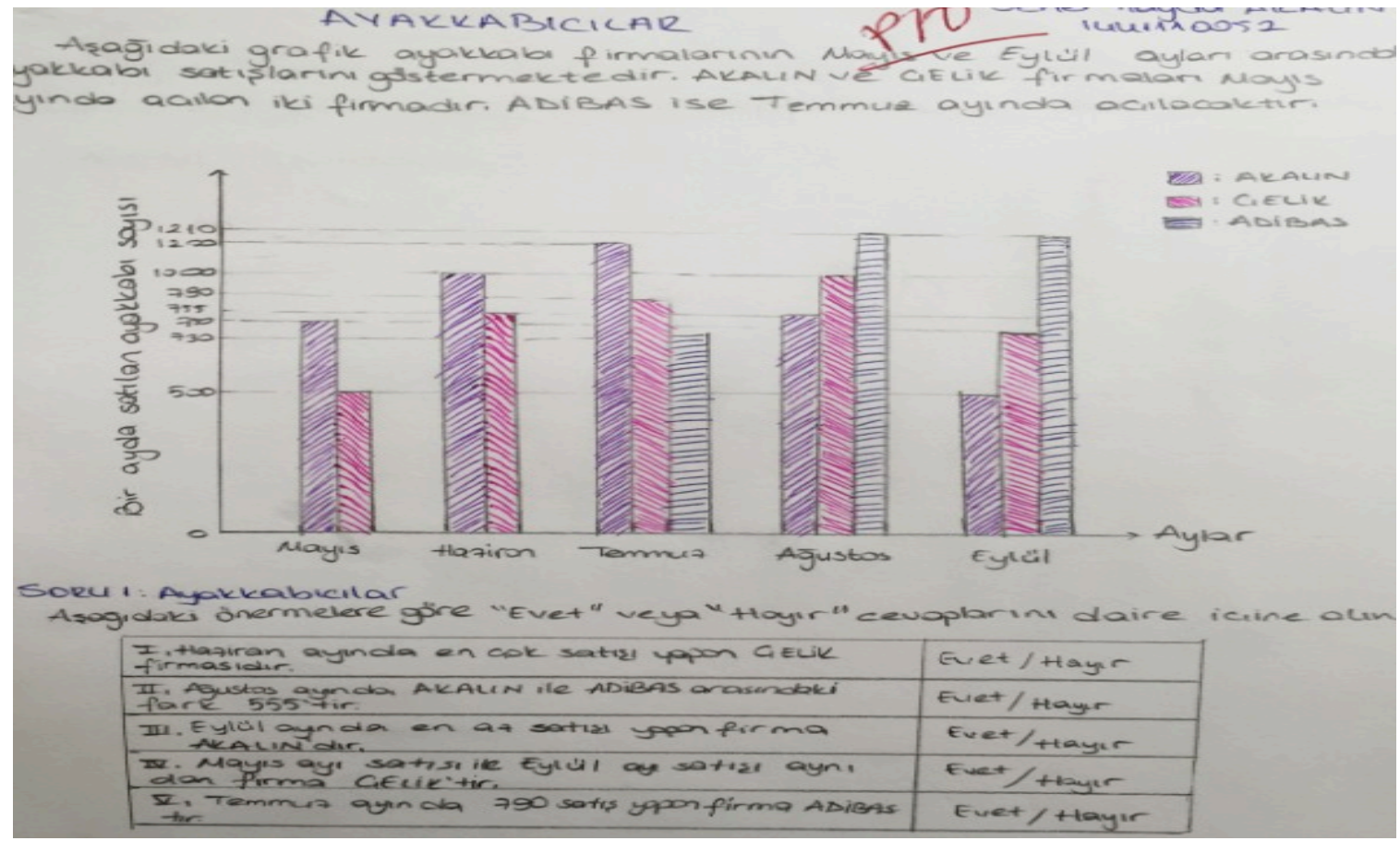

Şekil 6. ÖA10' un kurmuş olduğu mesleki bağlaml problem

ÖA10 öğretmen adayı farklı ayakkabı firmalarının Mayıs-Eylül ayları arasında yapmış oldukları satışları sütün grafiğinden yararlanarak sunmuştur. Öğretmen adayı mesleki bağlamda kurmuş olduğu bu problemde ayakkabı firmalarının satışlarının karşılaştırılmasına yönelik çeşitli önermelere yer vererek evet/hayır şeklinde sorulara oluşturmuştur. Örneğin öğretmen adayının birinci önermesi "Haziran ayında en çok satış yapan "ÇELIK" firmasıdır şeklindedir. 


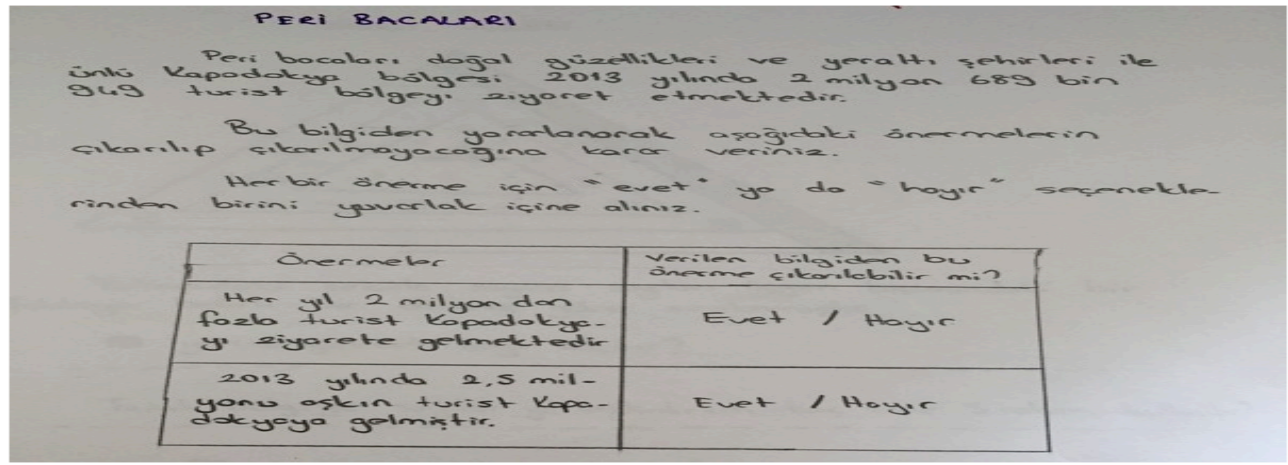

Şekil 7. ÖA45' in kurmuş olduğu toplumsal bağlamlı problem

ÖA45 öğretmen adayı Kapadokya' yı ziyaret eden turist miktarına ait bir istatistiğe yer vermiştir. Daha sonra öğretmen adayı öğrencilere çeşitli önermeler sunarak bu önermelerin doğruluğuna karar vermelerini istemiştir. Bu problemde öğretmen adayı bir ülkeye ait ulusal bir istatistiğe yer verdiği için toplumsal bağlamda bir problem kurmuştur.

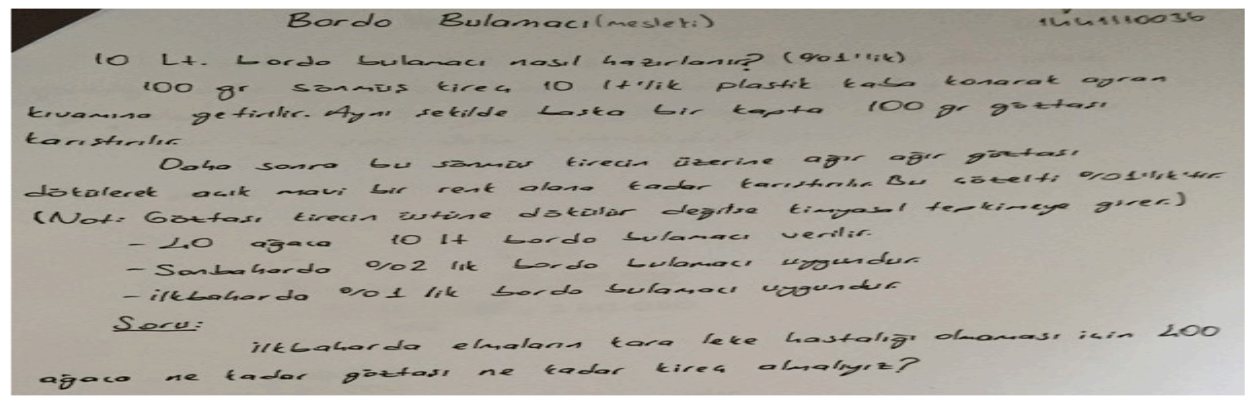

Şekil 8. ÖA23’ ün kurmuş olduğu bilimsel bağlamlı problem

ÖA23 öğretmen adayı ise elma ağaçlarının ilaçlanmasında kullanılan kimyasal maddelerin karışım içindeki oranlarını vermiş ve 400 ağaç için ne kadar kireç kullanılması gerektiğini sormuştur. Öğretmen adayı bu problemde kimyasal karışımları da probleme dahil ederek bilimsel bağlamda bir problem kurmuştur.

\section{Problemlerin İçerikleri}

Aşağıda yer alan Tablo 5' de öğretmen adaylarının kurmuş oldukları problemlerin PISA içerikleri açısından incelenmesine ait bulgular yer almaktadır.

Tablo 5. Öğretmen adaylarının kurdukları PISA problemlerinin içerikleri

\begin{tabular}{|c|c|c|c|c|c|c|c|c|}
\hline \multirow{2}{*}{$\begin{array}{l}\text { Problemler } \\
\text { İçerik }\end{array}$} & \multicolumn{2}{|c|}{ Problem 1} & \multicolumn{2}{|c|}{ Problem 2} & \multicolumn{2}{|c|}{ Problem 3} & \multicolumn{2}{|c|}{ Toplam } \\
\hline & $\mathrm{f}$ & $\%$ & $\mathrm{f}$ & $\%$ & $\mathrm{f}$ & $\%$ & $\mathrm{f}$ & $\%$ \\
\hline $\begin{array}{l}\text { Nicelik (Sayılar ve } \\
\text { İşlemler) }\end{array}$ & 31 & 56.36 & 24 & 43.63 & 12 & 21.81 & 67 & 40.6 \\
\hline $\begin{array}{l}\text { Değişim ve İlişkiler } \\
\text { (Cebir) }\end{array}$ & 5 & 9.09 & 8 & 14.54 & 8 & 14.54 & 21 & 12.72 \\
\hline $\begin{array}{l}\text { Uzay ve Şekil } \\
\text { (Geometri ve Ölçme) }\end{array}$ & 8 & 14.54 & 13 & 23.63 & 12 & 21.81 & 33 & 20 \\
\hline $\begin{array}{l}\text { Belirsizlik (Veri } \\
\text { İșleme-Olasilık) }\end{array}$ & 11 & 20 & 10 & 18.18 & 23 & 41.81 & 44 & 26.66 \\
\hline Toplam & 55 & 100 & 55 & 100 & 55 & 100 & 165 & 100 \\
\hline
\end{tabular}

Tablo 5' de öğretmen adaylarının en fazla (\% 40.6) "Nicelik (Sayllar ve Isslemler)" içeriğine ilişkin problem kurmayı tercih ettikleri görülmektedir. Buna rağmen öğretmen adayları en az (\% 12.72) problemi ise "Değişim ve Illişkiler (Cebir)" içeriğine yönelik 
kurmuşlardır. Bu bağlamda, ÖA18, ÖA46, ÖA24 ve ÖA27 öğretmen adaylarının farklı PISA içeriklerine yönelik kurmuş oldukları problem örneklerine yer verilmiştir.

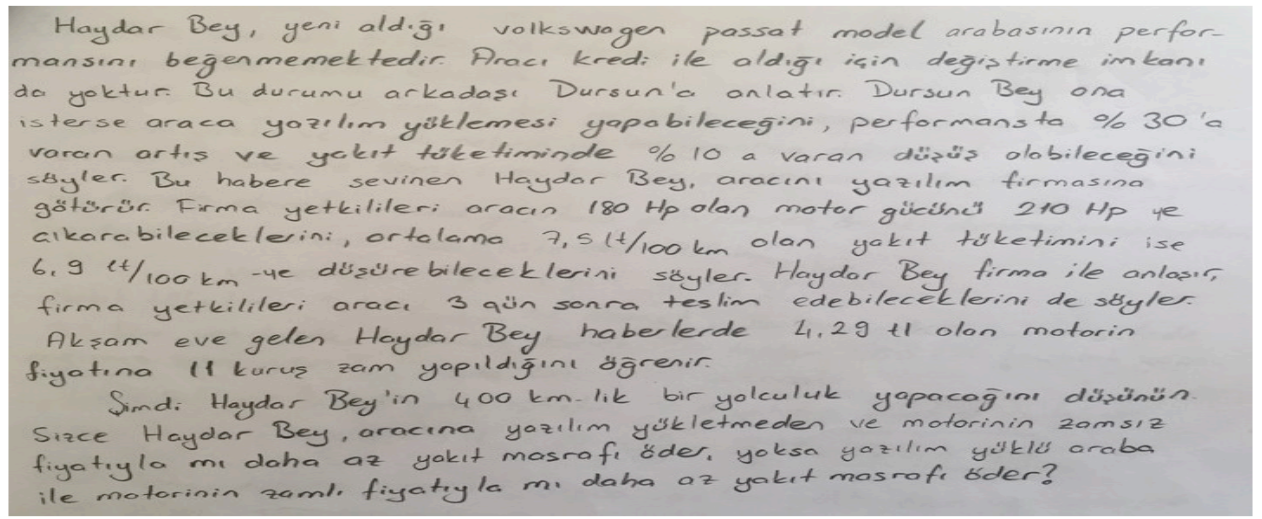

Şekil 9. ÖA18' in nicelik içeriğine yönelik kurmuş olduğu problem

ÖA18 öğretmen adayı kurmuş olduğu problemde, bir araç modelinin hangi koşullar altında ne kadar yakıt tükettiğine dair çeşitli veriler verip 400 km' lik bir yolculukta bu aracın ne kadar yakıt tüketeceğini sormuştur. Öğrencilerin bu problemi çözebilmesi için aritmetik işlemler ve yüzde kavramını kullanmaları gerektiği için bu problemin "Nicelik" içeriğine yönelik olduğu söylenebilir.

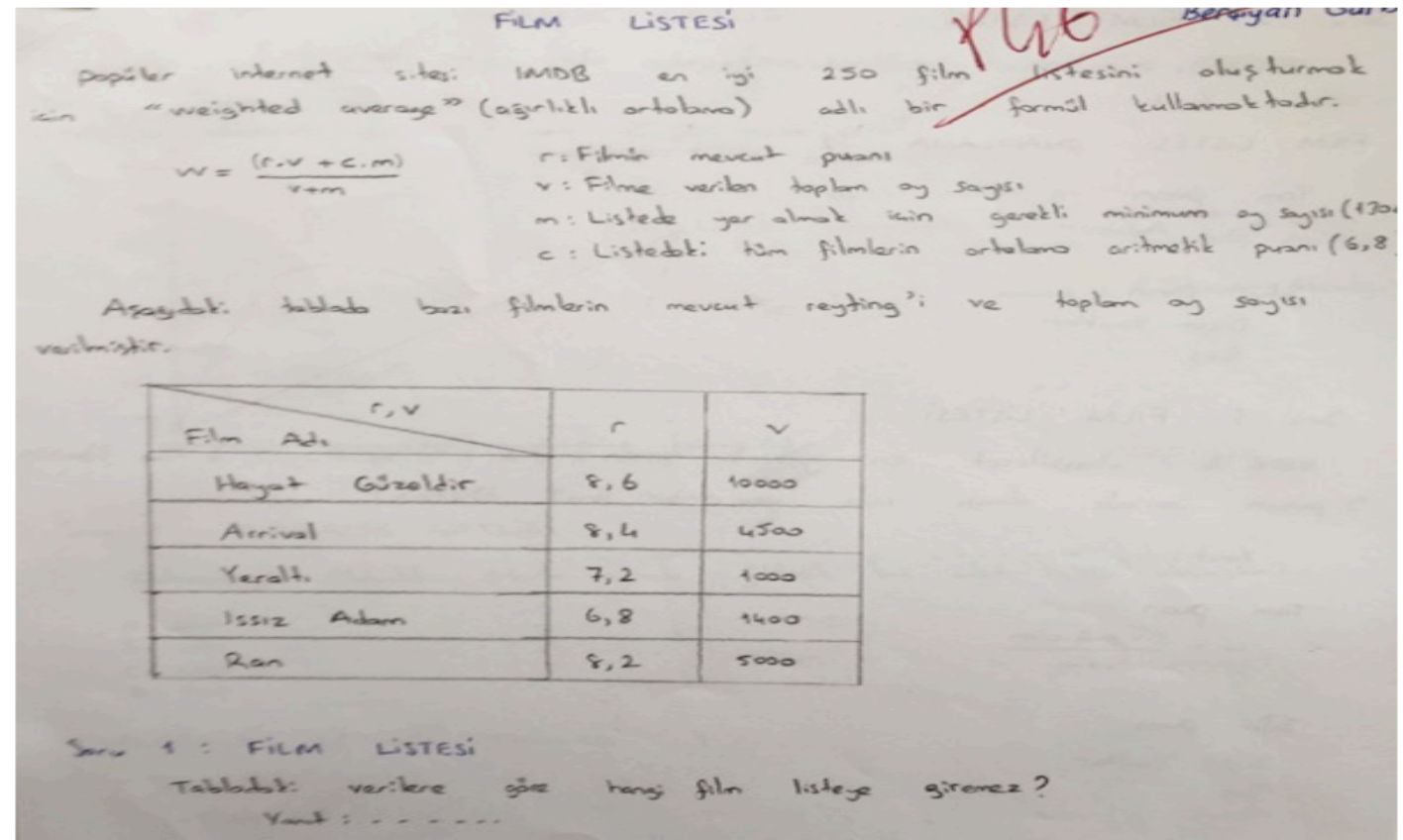

Şekil 10. ÖA46' nın değişim ve ilişskiler içeriğine yönelik kurmuş olduğu problem

ÖA46 öğretmen adayı bir filmin IMDB en iyi 250 film arasına girebilmesi için kullanılan bir formüle yer vermiştir. Öğretmen adayı daha sonra öğrencilerden verilen filmlerin bu listeye girip giremeyeceğini bulmalarını istemiştir. Öğrencilerin bu problemi çözerken bir formülü kullanmaları gerektiği için bu problem "Değişim ve İlişkiler" içeriği olarak değerlendirilmiştir. 


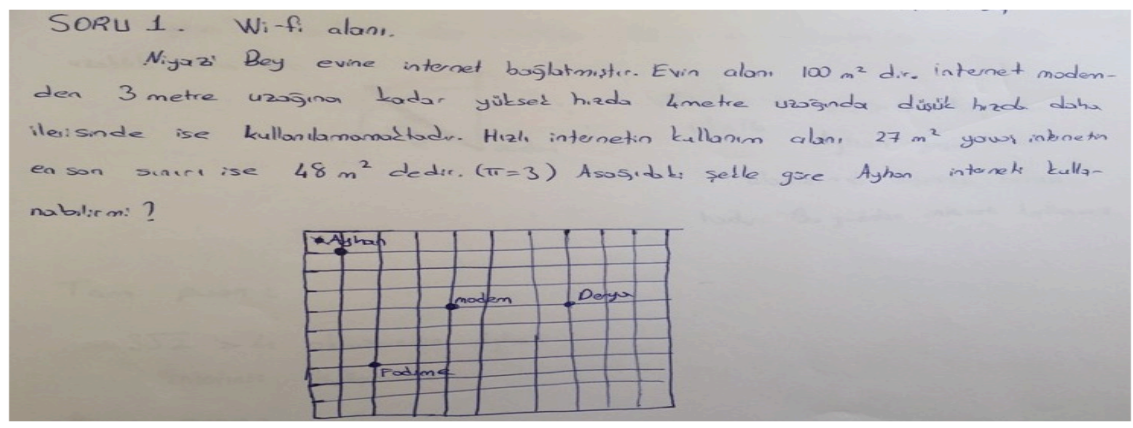

Şekil 11. ÖA24' ün uzay ve şekil içeriğine yönelik kurmuş olduğu problem

ÖA24 öğretmen adayı kurmuş olduğu problemde bir wi-fi ağının nasıl bir alanda etkili bir şekilde çektiği ve kişilerin konumları hakkında bilgiler vermiştir. Daha sonra öğretmen adayı öğrencilerden konumu verilen kişilerin bu wi-fi ağından etkili bir şekilde yararlanıp yararlanamadığını tespit etmelerini istemiştir. $\mathrm{Bu}$ problemin çözülmesi için öğrencilerin dairenin alan formülünü uygulaması gerektiği için bu problem "Uzay ve Şekil” içeriğine dâhil edilmiştir.

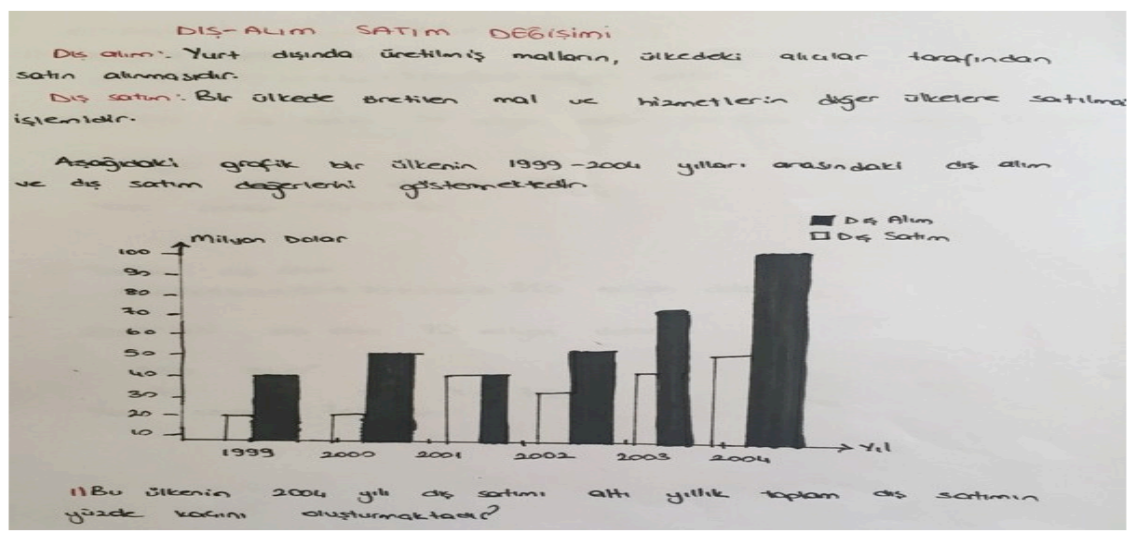

Şekil 12. ÖA27' nin belirsizlik içeriğine yönelik kurmuş olduğu problem

ÖA27 öğretmen adayı bir ülkenin 1999-2014 yılları arasındaki ticaret verilerine sütun grafiği yardımıyla özetlemiştir. Öğretmen adayı bu problemde bir veri setini bir grafik yardımıyla ifade ettiği ve ögrencilerden grafiği yorumlamayı istediği için hazırlamış olduğu problemin "Belirsizlik" içeriğine ait olduğu söylenebilir.

\section{Problemlerin Matematiksel Becerileri}

Aşağıda yer alan Tablo 6' da öğretmen adaylarının kurmuş oldukları problemlerin PISA matematik becerileri açısından incelenmesine ait bulgular yer almaktadır.

Tablo 6. Öğretmen adaylarının kurdukları PISA problemlerinin matematiksel becerileri

\section{\begin{tabular}{lllll}
\hline Problemler & Problem 1 & Problem 2 & Problem 3 & Toplam
\end{tabular}}

\begin{tabular}{lcccccccc}
\hline Beceri & $\mathrm{f}$ & $\%$ & $\mathrm{f}$ & $\%$ & $\mathrm{f}$ & $\%$ & $\mathrm{f}$ & $\%$ \\
\hline Üretici (Uygulama) & 34 & 61.81 & 27 & 49.09 & 25 & 45.45 & 86 & 52.12 \\
$\begin{array}{l}\text { İlişkilendirici } \\
\text { (Yorum Yapma) }\end{array}$ & 18 & 32.72 & 23 & 41.81 & 23 & 41.81 & 64 & 38.78 \\
$\begin{array}{l}\text { Yansitıc1 } \\
\text { (Formüle Etme) }\end{array}$ & 3 & 5.45 & 5 & 9.09 & 7 & 12.72 & 15 & 9.09 \\
\hline Toplam & 55 & 100 & 55 & 100 & 55 & 100 & 165 & 100 \\
\hline
\end{tabular}


Tablo 6' da matematik öğretmeni adaylarının daha çok üretici (\% 52.12) ve ilişkilendirici (\% 38.78) beceri gerektiren problemler kurdukları görülmektedir. Buna rağmen ögretmen adaylarının yansıtıcı (\% 9.09) beceri gerektiren problem kurmayı ise daha az tercih ettikleri söylenebilir. Bu bağlamda; ÖA38, ÖA28 ve ÖA31 öğretmen adaylarının kurmuş oldukları ve farklı matematiksel beceri gerektiren problem örneklerine yer verilmiştir.

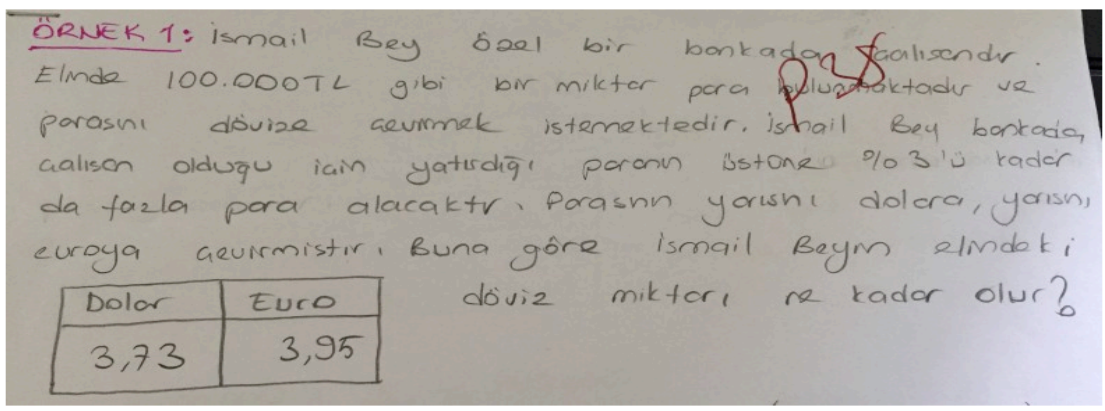

Şekil 13. ÖA38' in üretici beceriye yönelik kurmuş olduğu problem

ÖA38 öğretmen adayı bir banka çalışanın elinde bulunan paraları dövize çevirmesini konu alan bir problem kurmuştur. $\mathrm{Bu}$ problemde öğrencilerin temel aritmetik işlemler kullanarak problemi çözebilmeleri beklendiği için bu problemin üretici becerileri ölçmeye dönük bir problem olduğu söylenebilir.

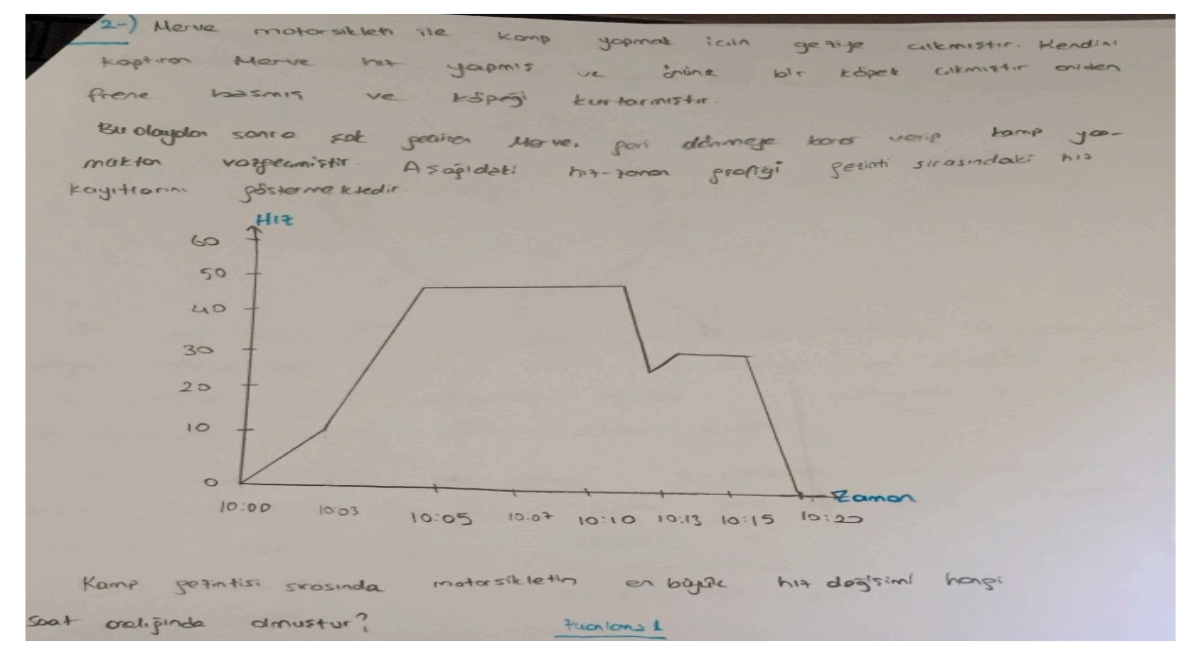

Şekil 14. ÖA28' in ilişskilendirici beceriye yönelik kurmuş olduğu problem

ÖA28 öğretmen adayı bir motosiklet gezisi sırasında yapılan hız değişimlerini bir çizgi grafiği yardımıyla göstermişlerdir. Öğretmen adayı öğrencilerden grafikte verileri yorumlayarak verilen soruları yanıtlamalını istemektedir. Yani öğretmen adayı ilişkilendirici beceri gerektiren bir problem kurmuştur. 


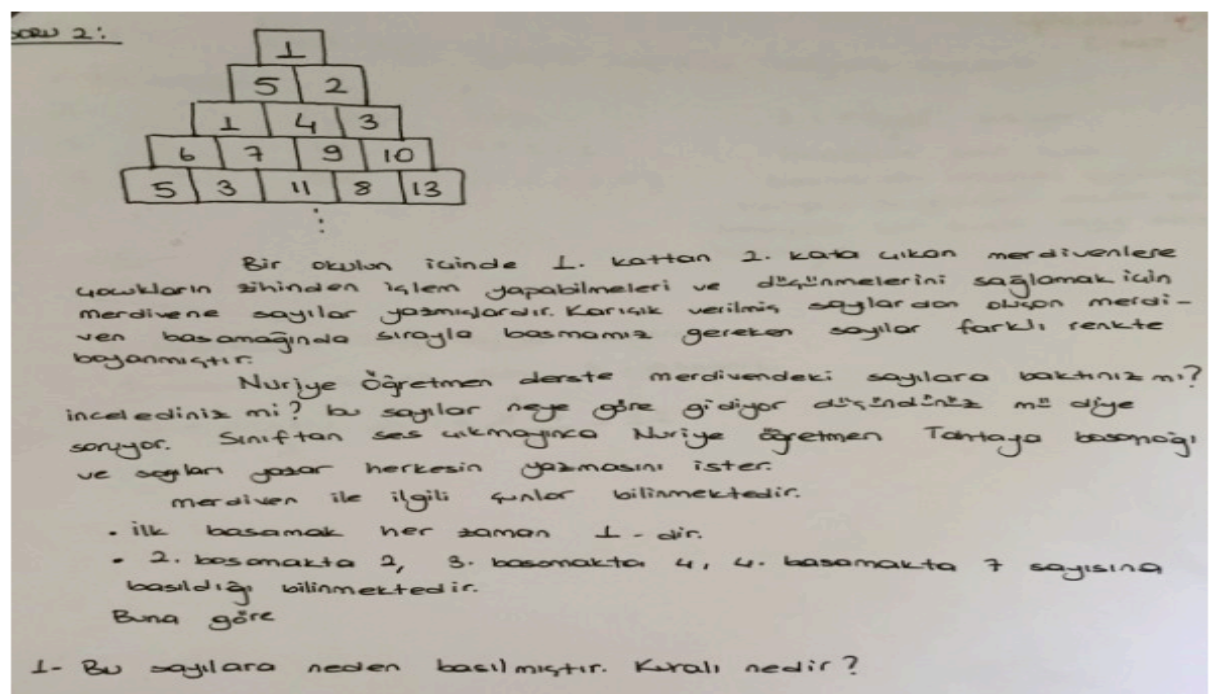

Şekil 15. ÖA31' in yansitıcı beceriye yönelik kurmuş olduğu problem

ÖA31 öğretmen adayı çocukların zihinden işlem yapma becerilerini geliştirmek amacıyla bir okulun merdivenlerinin bir sayı örüntüsüyle kaplandığını ifade etmiştir. Öğretmen adayı bu problemde öğrencilerden bu örüntünün kuralını değişkenler yarımıyla ifade etmelerini istediği için bu problemin yansıtıcı becerileri içerdiği söylenebilir.

\section{Problemlerin Çözümünde Kullanılan Stratejiler}

Aşağıda yer alan Tablo 7' de öğretmen adaylarının kurmuş oldukları PISA problemlerin problem çözme stratejileri açısından incelenmesine ait bulgular yer almaktadır.

Tablo 7. Öğretmen adaylarının kurdukları PISA problemlerinin problem çözme stratejileri

\begin{tabular}{lcccccccc}
\hline Problemler & \multicolumn{1}{l}{ Problem 1 } & \multicolumn{1}{c}{ Problem 2 } & Problem 3 & \multicolumn{3}{c}{ Toplam } \\
\hline Stratejiler & $\mathrm{f}$ & $\%$ & $\mathrm{f}$ & $\%$ & $\mathrm{f}$ & $\%$ & $\mathrm{f}$ & $\%$ \\
\hline Sistematik Liste Yapma & 2 & 3.63 & - & - & 2 & 3.63 & 4 & 2.42 \\
Tahmin & 1 & 1.81 & - & - & - & - & 1 & 0.6 \\
Diyagram Çizme & 6 & 10.9 & 6 & 10.9 & 4 & 7.27 & 16 & 9.69 \\
$\begin{array}{l}\text { Bağıntı Bulma } \\
\text { (İlişki Arama) }\end{array}$ & 3 & 5.45 & 5 & 9.09 & 1 & 1.81 & 9 & 5.45 \\
$\begin{array}{l}\text { Muhakeme Etme } \\
\text { Değişken Kullanma }\end{array}$ & 10 & 18.18 & 15 & 27.27 & 13 & 23.63 & 38 & 23.03 \\
$\begin{array}{l}\text { Aritmetik İşlemlerden } \\
\text { Yararlanma }\end{array}$ & 25 & 14.54 & 10 & 18.18 & 13 & 23.63 & 31 & 18.78 \\
\hline Toplam & 55.45 & 19 & 34.54 & 22 & 40 & 66 & 40 \\
\hline
\end{tabular}

Tablo 7' de matematik öğretmeni adaylarının en fazla ( $\%$ 40) aritmetik işlemler yarımıyla çözülebilen problemleri kurmayı tercih ettikleri görülmektedir. Ayrıca öğretmen adayları değişken kullanma (\% 18.78) ve muhakeme etme (\%23.03) stratejilerinin kullanmayı gerektiren problemleri de siklıkla tercih ettikleri söylenebilir. Buna rağmen öğretmen adaylarının sistematik liste yapma, tahmin etme, diyagram çizme ve bağıntı bulma gibi stratejileri kullanmayı gerektiren problemler kurmayı ise çok az tercih ettikleri söylenebilir. Bu bağlamda, ÖA10 ve ÖA4 öğretmen adaylarının kurmuş oldukları ve farklı stratejilerle çözülebilen problem örneklerine yer verilmiştir. 


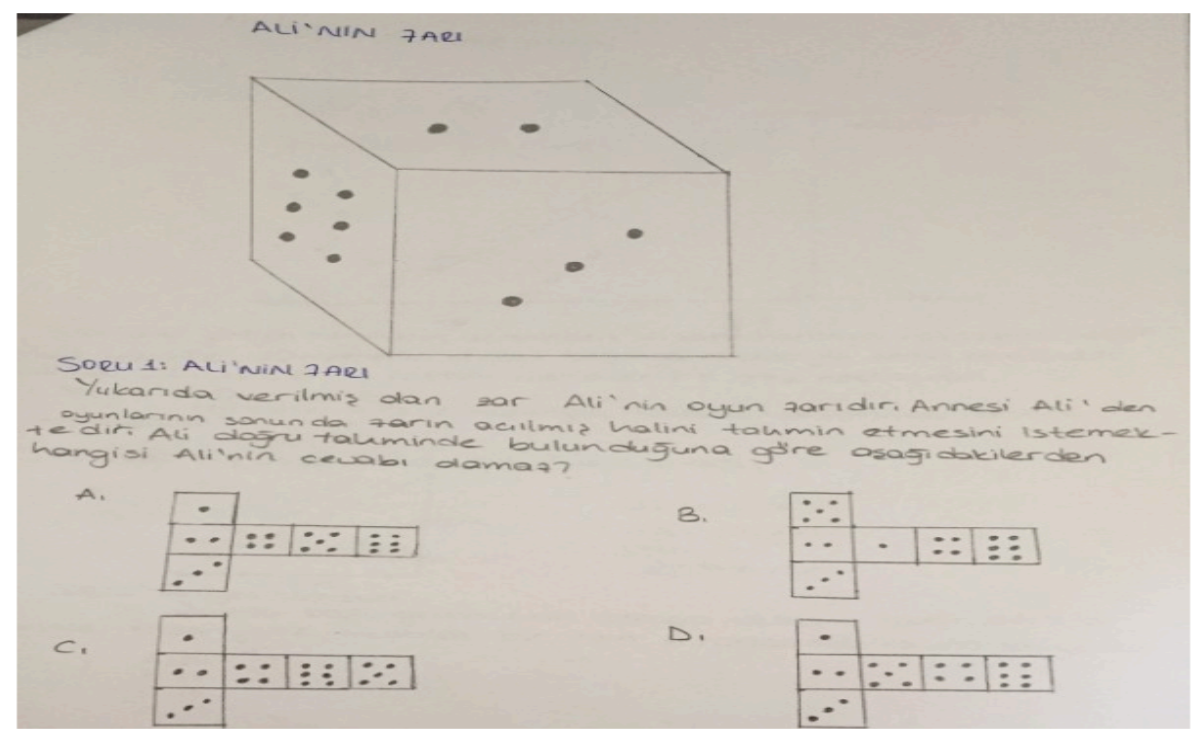

Şekil 16. ÖA10' un diyagram çizme stratejisine yönelik kurmuş olduğu problem

ÖA10 öğretmen adayı bir oyun esnasında 3 yüzündeki rakamların belli olduğu fakat diğer yüzlerindeki rakamların gözükmediği bir zarın açılmış halinin seçeneklerden hangisindeki gibi olamayacağını sormuştur. Öğrencilerin bu problemi çözebilmeleri için küpün açınımını yapmaları gerektiği için bu problemin diyagram çizme stratejisini kullanmayı gerektirdiği söylenebilir.

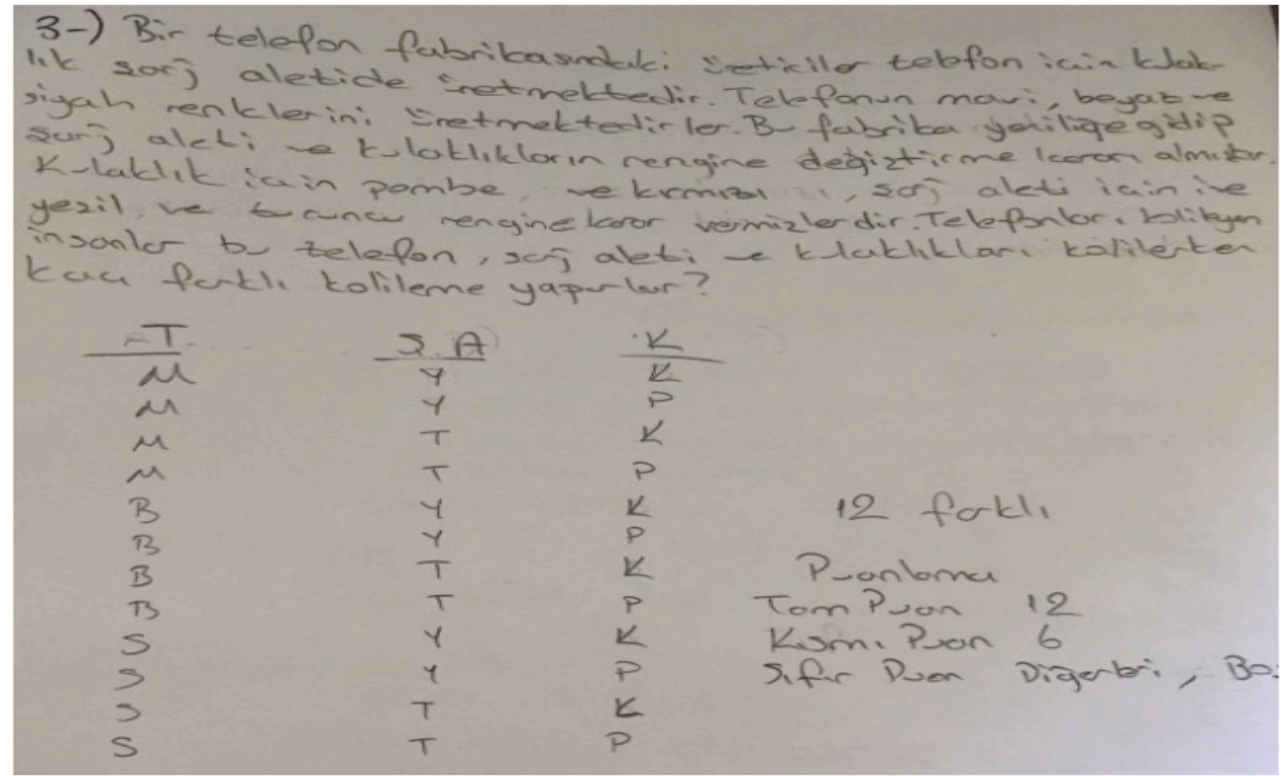

Şekil 17. ÖA4' ün sistematik liste yapma stratejisine yönelik kurmuş olduğu problem

ÖA4 öğretmen adayı ise bir telefon üretim fabrikasında yer alan farklı renkte telefon, kulaklık ve şarj cihazlarının kaç farklı şekilde kullanabileceğine yönelik bir problem kurmuştur. Öğretmen adayının hazırlamış olduğu çözümde, bu problemi tüm ihtimalleri sistematik bir liste yardımıyla sıralayıp sonuca ulaştığı görülmektedir.

\section{Problemlerin Veri Analiz Çerçeveleri}


Aşağıda yer alan Tablo 8' de öğretmen adaylarının kurmuş oldukları PISA problemlerine uygun veri analiz çerçevesi oluşturabilmelerine yönelik bulgular yer almaktadır.

Tablo 8. Öğretmen adaylarının kurdukları PISA problemlerine uygun veri analiz çerçevesi oluşturabilme becerilerinin incelenmesi

\begin{tabular}{|c|c|c|c|c|c|c|c|c|}
\hline \multirow{2}{*}{$\begin{array}{l}\text { Problemler } \\
\text { Puanlama }\end{array}$} & \multicolumn{2}{|c|}{ Problem 1} & \multicolumn{2}{|c|}{ Problem 2} & \multicolumn{2}{|c|}{ Problem 3} & \multicolumn{2}{|c|}{ Toplam } \\
\hline & $\mathrm{f}$ & $\%$ & $f$ & $\%$ & $\mathrm{f}$ & $\%$ & $f$ & $\%$ \\
\hline $\begin{array}{l}\text { Tam Doğru Kategorisi } \\
\text { İçin Açılklama Yapma }\end{array}$ & 53 & 96.36 & 54 & 98.18 & 55 & 100 & 162 & 98.18 \\
\hline $\begin{array}{l}\text { Kismen Doğru } \\
\text { Kategorisi İçin } \\
\text { Aç1klama Yapma }\end{array}$ & 7 & 12.72 & 6 & 10.9 & 8 & 14.54 & 21 & 12.72 \\
\hline $\begin{array}{l}\text { Sifır Kategorisi İçin } \\
\text { Açıklama Yapma }\end{array}$ & 33 & 60 & 39 & 70.9 & 38 & 69.09 & 110 & 66.66 \\
\hline
\end{tabular}

Tablo 8' de matematik öğretmeni adaylarının neredeyse tamamının ( $\%$ 98.18) kurdukları PISA problemlerinin değerlendirilmesine yönelik tam doğru cevap kategorisi için açıklamalara yer verdiği görülmektedir. Ayrıca öğretmen adaylarının birçoğu da (\% 66.66) öğrencilerin hangi durumlarda sıfır puan alacağına dair açıklamalara yer verdiği görülmektedir. Buna rağmen çok az sayıda (\% 12.72) öğretmen adayı ise öğrencilerin hangi durumlarda kısmi puan alacağına dair açıklamalara yer vermiştir. PISA' da çoktan seçmeli ve kısa cevap gerektiren sorular için tam puan ve sıfır puan cevap kategorilerine yer verilmektedir. Açık uçlu sorular için ise tam puan, kısmi puan ve sıfır puan kategorilerine yönelik açıklamalara yer verilmektedir. Fakat bu çalışmada öğretmen adaylarının hazırlamış oldukları problemlerin \% 60' 1 açık uçlu olmasına rağmen kısmen doğru kategorisi için çözüm üreten problem oranının ise sadece \%12.72 olduğu görülmektedir. Yani öğretmen adaylarının kısmen doğru kategorisi için çözüm üretmekte zorlandıkları söylenebilir.

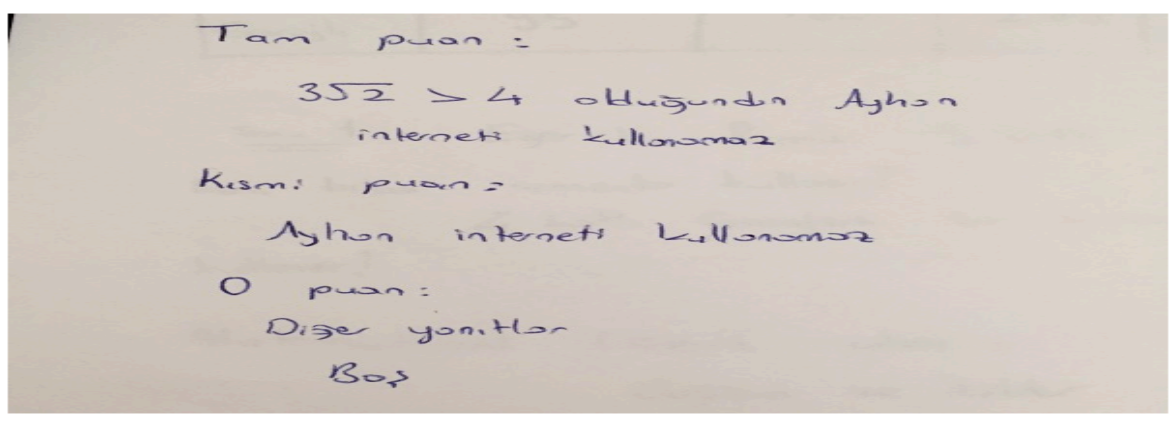

Şekil 18. ÖA24 öğretmen adayının veri analiz çerçevesi

ÖA24 öğretmen aday1 "Uzay ve Şekil” içeriğiyle ilgili kurmuş olduğu problemde, öğrencilerin tam puan alabilmesi için Ayhan Bey’in evinin modeme uzaklığıyla modem çekim alanının oluşturduğu dairenin çapının karşılaştırılması gerektiğini ifade etmiştir. Ayrıca öğretmen adayı öğrencilerin Ayhan Bey'in interneti kullanamayacağını ifade etmeleri durumunda ise kısmi puan verileceğini bunun dışındaki tüm cevapların ise sıfır puan kategorisine dâhil edileceğini ifade ettiği görülmektedir.

Aşağıda yer alan Tablo 9' da ÖA46 öğretmen adayının kurmuş olduğu PISA problemine ve bu problem için geliştirmiş olduğu veri analiz çerçevesine yer verilmiştir. 
Tablo 9. ÖA46 Öğretmen Adayının Veri Analiz Çerçevesi

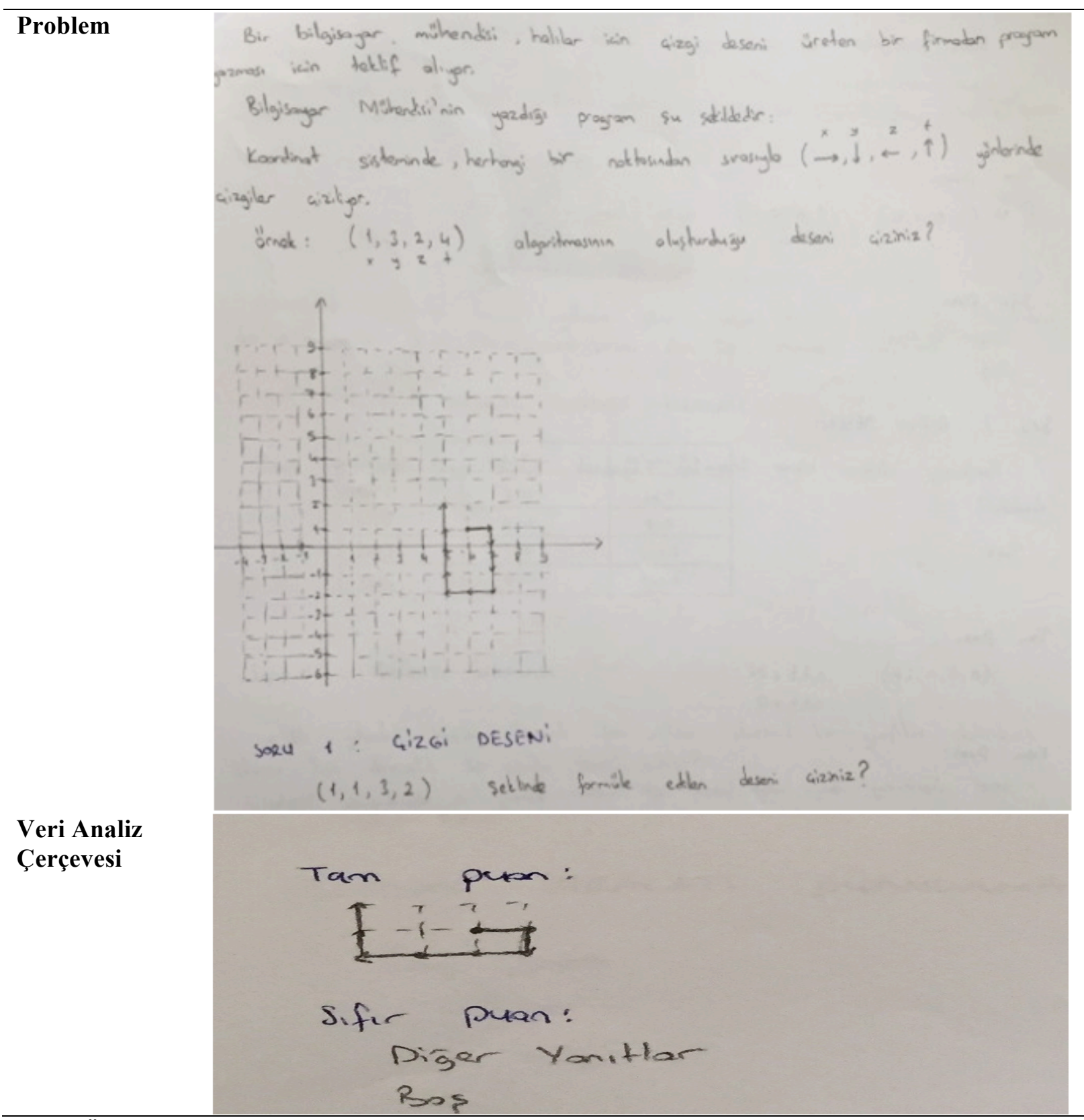

ÖA46 öğretmen adayı kurmuş olduğu problemin tam doğru ve sıfır cevap kategorileri için açıklamalara yer vermiştir. Fakat öğretmen adayı öğrencilerin hangi durumlarda kısmi puan alacağına dair herhangi bir açıklamaya yer vermemiştir.

\section{Sonuç ve Tartışma}

$\mathrm{Bu}$ çalışmada matematik öğretmeni adaylarının PISA sınavına uygun problem kurma becerilerini incelemek amacıyla gerçekleştirilmiştir. Çalışma sonucunda, öğretmen adaylarının PISA sınavının doğasına uygun problem kurabilme açısından başarılı oldukları görülmüştür. Diğer bir ifadeyle öğretmen adaylarının kurdukları problemler Zazkis ve Leiken (2008)'in ortaya koyduğu doğruluk kriteri açısından yeterli olduğu sonucuna ulaşılmıştır. PISA sınavının doğasına uygun olmayan problemlerde ise genellikle herhangi bir bağlama yer verilmeyerek günlük yaşamla matematik arasında ilişki kurulmamıştır. İlgili literatürde öğretmen ve öğretmen adaylarının PISA sınavına uygun problem kurma becerilerinden ziyade PISA problemlerini çözme becerileri, öğretim programlarının, ders kitaplarında ve merkezi 
sınavlarda yer alan problemlerin PISA bağlamında incelenmesine ve Türkiye' nin başarısının diğer ülkelerle karşılaştııılmasına yönelik çalışmalar yer almaktadır (Akarsu, 2009; Batur \& Ulutaş, 2013; Güler, 2013; İncikabı, Pektaş \& Süle, 2016; Yavuz, 2014). Yavuz (2014) öğretmen adaylarının PISA sınavında yer verilen problem çözme süreç becerilerinden; temsil ile gösterim, formülleştirme-kontrol etme, yansıtma becerilerinin sınıf düzeyine bağlı olarak yeterince gelişmediği sonucuna ulaşmıştır. İncikabı, Pektaş \& Süle (2016) ise ortaöğretime geçiş sınavında yer alan matematik sorularının çoğunlukla planlama ve uygulama sürecine odaklandığını ve kontrol etme ve yansıtma gibi üst düzey düşünme becerileri ölçen sorulara ise yeterince yer verilmediği sonucunu ortaya koymuşlardır. Akarsu (2009) hem Türkiye hem de Finlandiya için öz-yeterliğin matematik başarısının güçlü bir yordayıcısı olduğu fakat içe yönelik ve dışa yönelik motivasyonun ise matematik başarısının istatistiksel olarak anlamlı bir yordayıcısı olmadığı sonucuna ulaşmıştır. Bu çalışmaların aksine Gürbüz (2014) öğretmen adaylarının matematik okuryazarlığ 1 becerilerinin ve soru yazabilme becerilerinin gelişiminde yapılandırmacı öğrenme ortamları tasarlanması, tasarlanan öğretimin uygulanmasını araştırmıştır. Çalışma sonucunda öğretmen adaylarının çeşitli sınırlılıklar getirildiğinde soru yazmada zorlandıkları görülmüştür. Buna karşın herhangi bir kısıtlamanın olmadığı durumlarda ise öğretmen adayları soru yazmada daha başarılı olmuşlardır. Gürbüz (2014) çalışmasına paralel olarak bu çalışmada da öğretmen adaylarına herhangi bir sınırlama getirilmemiştir ve öğretmen adayları problem kurmada başarılı olmuşlardır. Bundan dolayı öğretmen ve öğretmen adaylarının daha yaratıcı, orijinal ve sıra dışı problem kurabilmeleri için özgürce problem kurabilecekleri ortamlar sağlanmalıdır.

Öğretmen adayları soru türü açısından daha çok açık uçlu problemler kurarken bağlam açısından daha çok kişisel ve mesleki bağlam içeren problemler kurmuşlardır. Ayrıca çok az sayıda öğretmen adayı ise herhangi bir bağlam içermeyen problemlere yer vermişlerdir. Öğretmen adayları içerikleri açısından daha çok nicelik (sayılar ve işlemler) içeriğine yer verirken matematiksel beceri bakımından ise daha çok üretici beceri gerektiren problemler kurmuşlardır. Diğer bir ifadeyle, öğretmen adayları daha çok verilen değerleri bir bağıntıda yerine koymayı ve aritmetik işlemleri gerçekleştirmeyi gerektiren problemlere yer vermişlerdir. Sonuç olarak, öğretmen adayların PISA sınavının doğasına uygun problem kurmakta başarılı olmalarına rağmen, kurulan problemlerin bağlam, içerik, matematiksel beceri, soru türü ve problem çözme stratejileri gibi değişkenler açısından yeterince zengin olmadığ 1 sonucuna ulaşılmıştır. Benzer şekilde Demir (2015) öğretmen adaylarının belli kalıpların dışına çıkarak PISA sınavına uygun ve özgün soru üretmekte zorlandıklarını ifade etmiştir. Ayrıca çalışmaya katılan öğretmen adaylarının problem kurma sürecinde herhangi bir kısıtlamaya gidilmemesini bir engel olarak gördüklerini ifade etmişlerdir.

PISA sınavında öğrencilerin sorulara vermiş oldukları cevapların puanlanmasına tam puan, kısmen puan ve sıfır puan (yanlış/boş) şeklinde üç kategori yer almaktadır. (MEB, 2016). Bu bağlamda, öğretmen adaylarından öğrencilerin problemleri çözerken hangi cevapları verirlerse tam puan, hangi durumlarda kısmi puan ve hangi durumlarda sıfir puan alacaklarını ifade ettikleri bir veri analiz çerçeveleri hazırlamaları istenmiştir. Çalışma sonunda öğretmen adaylarının tam ve sıfır puan için veri analiz çerçevesi oluşturmada başarılı oldukları görülmüştür. Buna karşın öğretmen adayları kısmi puan için veri analiz çerçevesi oluşturmada ise zorlandıkları görülmüştür.

\section{Öneriler}

- Öğretmen adaylarının PISA ile ilgili farkındalıklarının artırılarak PISA doğasına uygun problem kurmaları teşvik edilebilir. 
- $\mathrm{Bu}$ çalışmada öğretmen adaylarının PISA doğasına uygun problem kurma becerileri incelenmiştir. Gelecek araştırmalarda öğretmenlerin bu konudaki becerileri incelenebilir.

- Ayrıca öğretmen adaylarının daha az tercih ettikleri öğrenme alanı, problem çözme stratejileri, süreç becerileri ve bağlamlara ilişkin daha çok problem kurmaları istenerek daha geniş bir yelpazede problem kurma becerisine sahip olmaları sağlanabilir.

\section{Kaynakça}

Akarsu, S. (2009). Özyeterlik, motivasyon ve PISA 2003 matematik okuryazarlı̆̆ı üzerine uluslararas1 bir karşılaştırma: Türkiye ve Finlandiya. Yayınlanmamış yüksek lisans tezi, Abant İzzet Baysal Üniversitesi Sosyal Bilimler Enstitüsü, Bolu.

Akay, H., Soybaş, D. ve Argün, Z. (2006). Problem kurma deneyimleri ve matematik öğretiminde açı-uçlu soruların kullanımı. Kastamonu Eğitim Dergisi, 14(1), 129-146.

Altun, M. (2008). Eğitim fakülteleri ve sınıf öğretmenleri için matematik öğretimi. Alfa Yayıncılık, Ankara.

Altun, M., Aydın, N., Akkaya, R.,\& Uzel, D. (2012). PISA perspektifinden ilköğretim 8. Sınıf öğrencilerinin matematik başarı düzeyinin tahlili. Retrieved from http://doktora2012.files.wordpress.com/2012/10/zpisa-kuyeb.doc.

Ball, D.L., Thames, M.H. \& Phelps, G.(2008). Content knowledge for teaching: what makes it special? Journal of Teacher Education , 59(5), $389-407$.

Batur, Z., \& Ulutaş, M. (2013). PISA ile Türkçe öğretim programındaki okuduğunu anlama kazanımlarının örtüşme düzeylerinin incelenmesi. The Journal of Academic Social Science Studies, 6(2), 1549-1563.

Berberoğlu, G. (2007). Türk bakış açısından PISA araştırma sonuçları. Konrad Adenauer Stiftung [Çevrimiçi: http://www. konrad.org.tr/Egitimturk/07girayberberoglu. pdf], Erişim tarihi: 09 Kasım, 2018.

Cankoy, O., \& Darbaz, S. (2010). Problem kurma temelli problem çözme öğretiminin problemi anlama başarısına etkisi. Hacettepe Üniversitesi Eğitim Fakültesi Dergisi, 38(38),11-24.

Creswell, J. W. (2011). Educational research: planning, conducting, and evaluating quantitative and qualitative research (4th Ed). Pearson Publications,Inc.

Çelik, A. ve Özdemir, E. Y. (2011). İlkögretim öğrencilerinin orantısal akıl yürütme becerileri ile oran-orantı problemi kurma becerileri arasındaki ilişki. Pamukkale Üniversitesi Eğitim Fakültesi Dergisi, 30(1), 1-11.

Demir, F. (2015). matematik okuryazarlığı soru yazma süreç ve becerilerinin gelişimi. Yayınlanmamış doktora tezi, Uludă̆ Üniversitesi, Bursa.

Denscombe, M. (2010). The good research guide: for small-scale social research projects (4th Edition). Open University Press.

English, L. D. (1997). The development of fifthgrade children's problem posing abilities. Educational Studies in Mathematics, 34(3), 183-217.

Ersoy, Y. (1997). Nitelikli matematik öğretmeni yetiştirme. Çăgdaş Ĕgitim,(22)237, 3-7.

Güzeller, C. O., Eser, M. T., \& Aksu, G. (2016). Study of the factors affecting the mathematics achievement of turkish students according to data from the programme for international student assessment (PISA) 2012. International Journal of Progressive Education, 12(2), 223-236.

Gonzales, N. A. (1998). A blueprint for problem posing. School Science and Mathematics, 94(2), 7885. 
Güler, H. K. (2013). Türk öğrencilerin pısa'da karşılaştıkları güçlüklerin analizi. Uludă̆ Üniversitesi Eğitim Fakültesi Dergisi, 26(2), 501-522.

Gürbüz, M. Ç. (2014). Matematik okuryazarlık öğretiminin PISA sorusu yazma ve matematik okuryazarlık düzeyleri üzerine etkisi. Yayımlanmamış Yüksek Lisans Tezi. Uludağ Üniversitesi, Bursa.

Işık, C., Işık, A. ve Kar, T. (2011). Matematik öğretmeni adaylarının sözel ve görsel temsillere yönelik kurdukları problemlerin analizi. Pamukkale Üniversitesi Eğitim Fakültesi Dergisi, 30(2), 39-49.

İncikabı, L., Pektaş, M., \& Süle, C. (2016). Ortaöğretime geçiş sınavlarındaki matematik ve fen sorularının pısa problem çözme çerçevesine göre incelenmesi. Journal of Kirsehir Education Faculty, 17(2), 649-662.

K1lıç, C. (2013). Turkish primary school teachers' opinions about problem posing applications: Students, the mathematics curriculum and mathematics textbooks. Australian Journal of Teacher Education (Online), 38(5), 144.

Kilpatrick, J. (1987) Problem Formulating: where do good problems come from? In A.H. Schoenfeld (Ed.) Cognitive Science and Mathematics Education, pp. 123-147. Hillsdale: Lawrence Erlbaum.

Korkmaz, E. ve Gür, H. (2006). Öğretmen adaylarının problem kurma becerilerinin belirlenmesi. Balıkesir Üniversitesi Fen Bilimleri Enstitüsü Dergisi, 8(1), 64-74.

Lowrie, T. (2002). Designing a Framework for Problem Posing: young children generating openended tasks, Contemporary Issues in Early Childhood, 3(3), 354-364.

Mcmillian, H. J.\& Schumacher, S. (2010). Research in education. Boston, USA: Pearson Education.

Milli eğitim Bakanlığı, (MEB) (2016). PISA 2015 Ulusal Raporu. Ankara: Milli Eğitim Bakanlığı.

Neuman, W. L. (2014). Social Research Methods: Qualitative and Quantitative Approaches: Pearson New International Edition. Pearson Education Limited.

Organisation for Economic Co-operation and Development (OECD). (2013a). PISA 2012 results: What students know and can do - student performance in mathematics, reading, and science (Volume I). PISA. OECD Publishing.

Organisation for Economic Co-operation and Development (OECD). (2013b). PISA 2012 results: What students know and can do - student performance in mathematics, reading, and science (Volume II) . PISA. OECD Publishing

Organisation for Economic Co-operation and Development (OECD). (2018). PISA 2015 results in focus. PISA, OECD Publishing.

Özenç, B., \& Arslanhan, S. (2010). PISA 2009 sonuçlarına ilişkin bir değerlendirme. Türkiye Ekonomi Politikaları Araştırma Vakfi.

Özer Y. \& Anıl D. (2011). Öğrencilerin fen ve matematik başarılarını etkileyen faktörlerin yapısal eşitlik modeli ile incelenmesi. Hacettepe Üniversitesi Eğitim Fakültesi Dergisi, 41(41), 313324.

Özer, Y. \& Özberk, E. H. (2011). PISA 2009:Türk öğrencilerin okuma becerileri, fen ve matematik okuryazarlı̆̆ının bazı değişkenler açısından incelenmesi. 20. Ulusal Eğitim Bilimleri Kurultayı. Burdur.

Patton, M. Q. (1987). How to use qualitative methods in evaluation. Newbury Park.

Rosli, R., Capraro, M. M., Goldsby, D., y Gonzalez, E. G., Onwuegbuzie, A. J., \& Capraro, R. M. (2015). Middle-grade preservice teachers' mathematical problem solving and problem posing. In Mathematical Problem Posing (pp. 333-354). Springer, New York, NY. 
Silver, E. A. (1994). On mathematical problem posing. For the Learning of Mathematics, 14(1), 1928.

Silver, E. A. ve Cai, J. (1996). An analysis of arithmetic problem posing by middle school students. Journal for Research in Mathematics Education, 27(5), 521-539.

Stoyanova, E. (2003). Extending students' understanding of mathematics via problem posing. The Australian Mathematics Teacher, 59(2), 32-40.

Stoyanova, E. \& Ellerton, N. F. (1996). A framework for research into students' problem posing. In P. Clarkson (Ed.), Technology in Mathematics Education (518-525). Melbourne: Mathematics Education Research Group of Australasia.

Xie, J., \& Masingila, J. O. (2017). Examining interactions between problem posing and problem solving with prospective primary teachers: A case of using fractions. Educational Studies in Mathematics, 96(1), 101-118.

Yavuz, E. (2014). İlköğretim matematik öğretmen adaylarının PISA'da tanımlanan problem çözme süreç yeterliliklerinin belirlenmesi. Yayımlanmamış Yüksek Lisans Tezi. Gazi Üniversitesi, Ankara.

Yıldırım, A. \& Şimşek, H. (2011). Sosyal bilimlerde nitel araştırma yöntemleri (8.baskı). Ankara: Seçkin Yayıncılık.

Yin, R. K. (2012). Applications of case study research (3rd ed). Thousand Oaks, CA: Sage.

Zazkis, R. \& Leikin, R. (2008). Exemplifying definitions: a case of a square. Educational Studies in Mathematics, 69(2),131. 
EK 1: Veri Analiz Çerçevesi

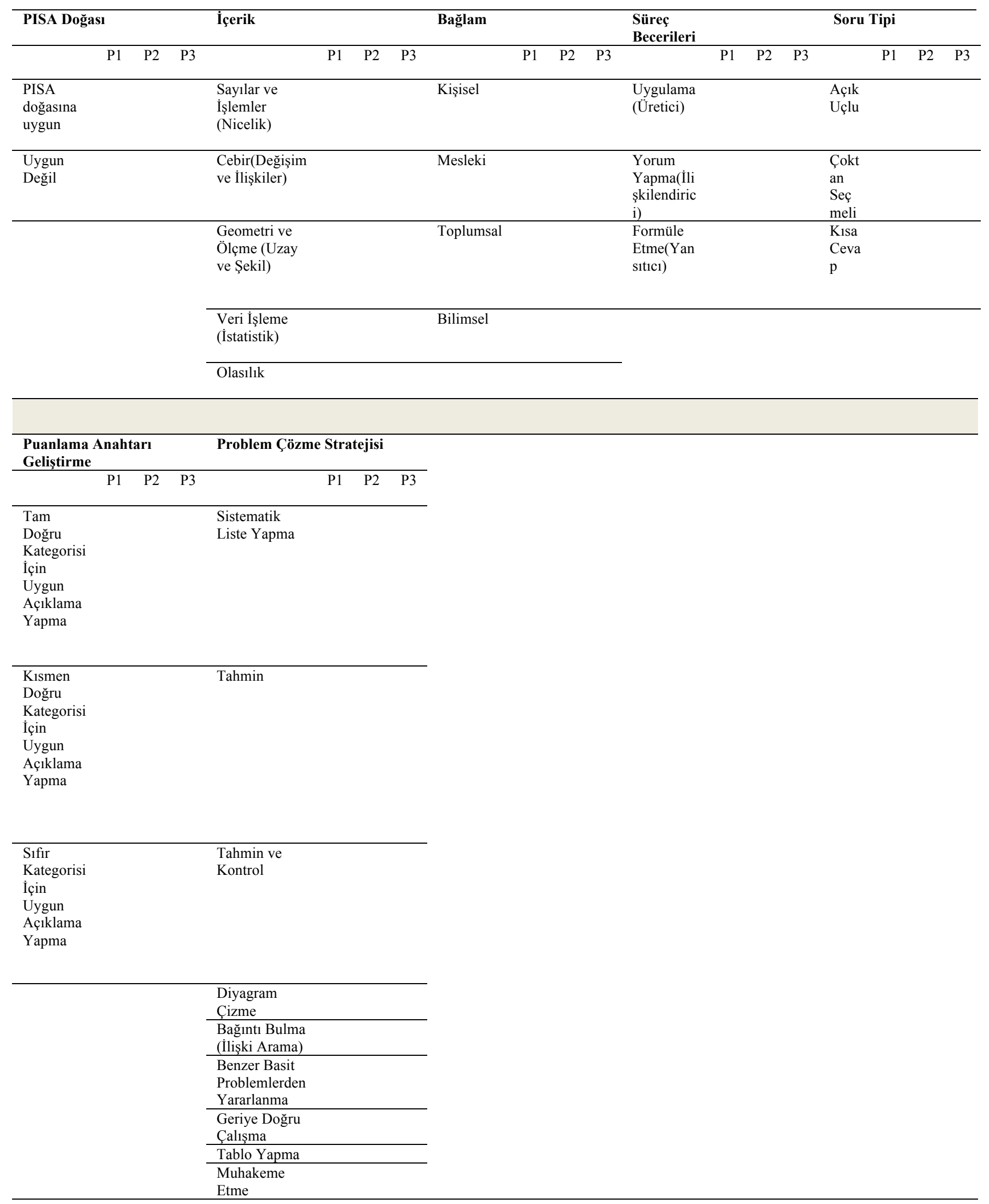

